\title{
Examining the impact of carbon price changes under a personalised carbon trading scheme for transport
}

\author{
David McNamara and Brian Caulfield ${ }^{1}$
}

\begin{abstract}
The research presented in this paper investigates the welfare effects of a Personal Carbon Trading Scheme (PCTS). A consumer surplus analysis is used to determine the welfare loss to individuals who undertake travel-to-work trips in the Dublin and the Western Border Region (WBR) of Ireland. Three $\mathrm{CO}_{2}$ price scenarios are analysed: a low, medium and high carbon price. These results are compared at an aggregate level for each electoral division to existing measures of deprivation derived from the Census 2006 to determine if electoral wards designated as relatively deprived also incur the largest welfare losses. The results are also compared to density of population in each electoral division to investigate any link between density levels and welfare changes, particularly in rural regions.

The welfare model found a significant divergence in the changes in consumer surplus between both study regions. While welfare changes were minimal in the low price scenario, divergences occurred in the medium and high price scenarios as individuals using more sustainable modes in urban areas benefited from the higher market price. Large welfare losses were found in the more rural WBR whilst most areas in Dublin were found to experience a welfare gain.
\end{abstract}

\section{Carbon reduction policies}

In Ireland, the transport sector has become one of the major sources of green house gas emissions growth in recent years. In 2009 transport emissions accounted for $21.1 \%$ of Ireland's green house gases (EPA, 2010). This was a 176\% increase on 1990 levels, second only to Cyprus amongst the 27 EU countries. Road transport emissions accounted for $97 \%$ of transport emissions. Evidently, significant reductions of road transport emissions, as part of overall GHG emissions is required in meeting Ireland's Kyoto targets. A number of supplyside and demand-side policies have been advocated to reduce $\mathrm{CO}_{2}$ emissions. Research has mainly focused on fiscal measures such the carbon taxation. These measures will be discussed in the following sections.

In 2010, a carbon tax on fuel and gas was introduced in Ireland. This tax was levied on transport and home heating fuels as well as natural gas. It currently stands at $€ 15$ per tonne of $\mathrm{CO}_{2}$. The idea of reducing $\mathrm{CO}_{2}$ emissions by imposing a tax is not a new concept. The idea of negating an externality using taxation was first suggested by Pigou (1952). Pigou (1952) argued that the agents who create the benefits or costs in an economy do not always have to bear the outcomes. A tax would internalise any negative outcomes while incentivising agents to reduce activities which would incur a tax. This type of tax is known as a Pigouvian tax. Using a Pigouvian type tax to reduce $\mathrm{CO}_{2}$ has become a popular policy tool subsequent to the signing of the Kyoto protocol in 1997. This treaty provided flexibility to implement a number of policies to share the burden of reduction amongst nation such as trading schemes. While the EU created the Emissions Trading Scheme to provide a pan-European mechanism to reduce $\mathrm{CO}_{2}$, many countries have implemented carbon taxes within each state as the primary

\footnotetext{
${ }^{1}$ Department of Civil, Structural and Environmental Engineering, Trinity College Dublin, Dublin 2, Ireland
} 
policy tool for reduction. One of the reasons for the popularity of taxation is the relative simplicity of levying a tax as opposed to designing and implementing a complex trading scheme. To date all of Norway, Sweden, Finland, Switzerland, Netherlands and Ireland have implemented various forms of carbon related taxation.

Early studies investigating measures to mitigate climate change have advocated the use of carbon taxation as a means of reducing $\mathrm{CO}_{2}$ (Symons et al., 1994, Baumol, 1972, Pearce, 1991). Baumol (1972) built on the work of Pigou in investigating the effectiveness of Pigouvian type taxes in reducing emissions. This approach also advocated using subsidies as a supplementary measure to incentivise polluters to reduce their emissions. Baumol (1972) suggested a persuasive case could be made for the use of taxation, although in reality the environmental outcomes would be less optimal than predicted. Pearse (1991) and Symons et al. (1994) both studied the potential effects of a carbon tax levied across the UK economy. Their conclusions endorsed the view that carbon taxes can effectively reduce emissions at a minimum cost to the economy. Another benefit cited is the 'double dividend' effect (Goulder, 1995). This is the concept that the tax will reduce emissions while substituting for revenues from so-called 'good' sources such as income tax.

Sovacool (2010) conducted a study of carbon taxation while comparing it to carbon trading in the USA. This article advocates using carbon taxes over other mechanisms such as carbon trading due to the price stability it provides, net benefits up to 16 times greater than other schemes, simplicity of implementation and a minimisation of transaction costs.

While the majority of research to date has focused on potential emissions reductions, recent studies have investigated equity. Ekins and Dresner (2004) modelled the equity effects of a carbon tax in the UK. The findings emphasise the importance of compensating the lowest income earners, who were found to be the largest net losers in the event of taxation being introduced. Despite including for measures to compensate low-income individuals in their model, some low-earners still remained the largest net losers. Callen et al. (2009) also studied the equity effects of a carbon tax in Ireland concluding that a tax would be regressive, costing the poorest households $€ 3$ euro per week while only costing the richest $€ 4$ per week. Compensation through social welfare payments was cited as a mechanism of redress; however, this would seem an unlikely course of action in the current economic climate.

Public Acceptability of carbon taxation has also been researched in recent years (Agrawal et al., 2010, Bristow et al., 2010). Agrawal (2010) found that up to 50\% would support some form of environmental taxation. Individuals with pro-environment or progovernment attitudes tended to be most likely to support these measures. This is a very high acceptance rate, taking into account most individual's aversion to new forms of taxation. In Britain, Bristow et al. (2010) carried out similar research to determine societal attitudes towards carbon taxation. This paper used a stated preference model to determine individual's attitudes to carbon taxation and carbon trading. This study predicted up to $70 \%$ acceptability of taxation under a number conditions. Acceptability of carbon taxation falls to under $50 \%$ when the proceeds of the tax are not explicitly stated by the Government. In contrast, acceptability of carbon trading was found to be as high as $80 \%$ is some cases in this study.

While some authors suggest that carbon taxes are the most efficient means of reducing emissions, the common thread from the literature reviewed in this section is one of a justification for taxation based on grounds of efficiency and cost effectiveness. However, research has shown that a flat carbon tax is an inherently regressive measure without compensatory mechanisms for lower income groups. Moreover, the environmental dividend is ambiguous. The research presented in this paper adds to the body of work in this area by examining the impacts that a carbon trading scheme would have and demonstrates the large urban/rural divide if such a policy were implemented. 


\section{DATA SOURCE AND STUDY AREAS}

The primary data used in this research are taken from a subset of the Census of Population, 2006, which tabulates $1,834,472$ individual travel-to-work trips of persons over the age of 15 and working for payment or profit and includes 32 separate variables detailing a number of travel specific and socio-economic characteristics (CSO, 2006). The census data used in this study does not include income levels. Variables such as socio-economic group are used in this study as a proxy for income.

The two study regions are examined in this paper the WBR and the Dublin region. According to the Census of Population, 2011 the population of the Dublin region was $1,187,176$ persons (CSO, 2011). The population of the WBR region was 698,971 persons in 2011. Aside from the rural-urban differential, the geographical size of each region differs significantly. Dublin is a small densely populated region with covering $921 \mathrm{~km}^{2}$, while the rural WBR is a much larger sprawling region covering $25,700 \mathrm{~km}^{2}$. The geographical spread of these regions is illustrated in Figure 1. From transportation perspective the main difference between the WBR and Dublin is that $62 \%$ of those living in the WBR drive to work alone on a regular basis compared to $49 \%$ in Dublin.

\section{Figure 1: Dublin and WBR Regions}

\section{Personal carbon trading scheme}

In order to estimate the average annual emissions, the emissions per trip had to be calculated. This was estimated by multiplying the distance travelled by an emissions factor (specific to each mode) and then adjusted for vehicle occupancy. McNamara and Caulfield (2011a) describe the approach used to estimate emissions in greater detail. The PCTS follows a cap and share approach. Under this scheme the average annual emissions for individuals daily commute was calculated. This was found to be $2.5 \mathrm{~kg}$ of $\mathrm{CO}_{2}$. The scheme would allocate a free quota of $2.5 \mathrm{~kg}$ of $\mathrm{CO}_{2}$ for each commuting trip, and individuals that emit more that this would have to purchase a carbon quota from individuals that emit less than their own quota. This $2.5 \mathrm{~kg}$ of $\mathrm{CO}_{2}$ is called the carbon cap.

The effect of imposing a cap on individuals is presented in Table 1. This shows the percentage of commuters who would fall above and below a cap in each study region. A cap based on average national emissions would leave $11.2 \%$ of commuters above the cap in Dublin, much lower than the national average of $26 \%$. In the WBR, the cap would result in $33.5 \%$ of commuters falling above the cap. The percentage share of individuals in the WBR above the cap at both levels is therefore significantly higher than the National and Dublin datasets.

\section{Table 1: Division of individuals above the cap}

\section{Welfare Analysis}

The welfare estimation is also be subject to a scenario analysis based on a low, medium and high $\mathrm{CO}_{2}$ prices. The prices chosen are listed in Table 2 and are determined based on historical European Union Allowances market prices. The historical low, high and current prices of allowances in September 2011 are used in this analysis ${ }^{2}$.

\footnotetext{
${ }^{2}$ Historical Prices garnered from EUA 'Dec 2011' Market data. Obtained from www.pointcarbon.com
} 


\section{Table 2: $\mathrm{CO}_{2}$ price in each market scenario}

\section{Travel Cost Calculations}

To determine the pre-PCTS and post-PCTS cost of travel for commuters, travel cost equations are used. The equations estimate the cost of travelling by slow modes (walking and cycling), private vehicle (car, motorcycle, van) and by public transport (bus and rail) in Ireland. To determine the pre-PCTS and post-PCTS travel costs for commuters, travel cost equations are used (Steer Davies Gleave, 2009). These equations estimate the cost of travelling by walking, cycling, private vehicle and public transport in Ireland. The parameters vary across three separate peak time periods in which a commuter undertakes a trip: 7-8AM, 8-9AM and 9-10AM. Parameters are related to distance travelled, travel time, public transport fares and tolls occurring in daily trips for three types of commute trips: slow mode trips (walk and cycle), private vehicle trips (car, motorcycle, van) or public transport (bus and train). The parameters used in this paper are detailed in Table 3. These parameters are then inputted into cost equations 1-7 to determine each individual's commute trip cost.

\section{Table 3: Travel Parameters used}

The pre-PCTS travel cost equations for slow modes, private vehicles and public transport are:

\section{Slow Modes}

$$
\text { Cost }(\text { Slow Mode })=\left(\frac{\text { Distance }}{\text { Speed }}\right) * \text { Trip Time } * \text { VOT }
$$

\section{Private Vehicle Travel}

$$
\begin{aligned}
& \operatorname{Cost}(7-8 A M)=(\text { Distance } * \text { HWAY } 1)+(\text { Trip Time } * \text { HWAY4 })+\left(\frac{\text { Toll cost }}{\text { HWAY7 *VOT }}\right) \text { (Eq. 2) } \\
& \operatorname{Cost}(8-9 A M)=(\text { Distance } * \text { HWAY2 })+(\text { Trip Time } * \text { HWAY5 })+\left(\frac{\text { Toll cost }}{\text { HWAY8 } * \text { VOT }}\right) \text { (Eq. 3) } \\
& \operatorname{Cost}(9-10 A M)=(\text { Distance } * \text { HWAY3 })+(\text { Trip Time } * H W A Y 6)+\left(\frac{\text { Toll cost }}{\text { HWAY9 } * \text { VOT }}\right)(\text { Eq. } 4)
\end{aligned}
$$


Public Transport

$$
\begin{aligned}
& \operatorname{Cost}(7-8 A M)=(\text { In Venicle Time } * \text { PT } 4)+\left(\frac{\text { PT Fare }}{\text { PT } 1 * \text { VOT }}\right) \\
& \operatorname{Cost}(8-9 A M)=(\text { In Venicle Time } * \text { PT5 })+\left(\frac{\text { PT Fare }}{\text { PT2 } * \text { VOT }}\right) \\
& \operatorname{Cost}(9-10 A M)=(\text { In Venicle Time } * \text { PT } 6)+\left(\frac{\text { PT Fare }}{\text { PT } 3 \text { VOT }}\right)
\end{aligned}
$$

Distance is calculated in $\mathrm{km}$ and trip time is calculated in minutes using the census data. Public transport (PT) fare is the cost of a public transport ticket and value of time (VOT) is the value of time to commuters. The value of time is calculated by the Irish National Transport Authority as $€ 9.476$ per hour in 2006 prices. Speeds for slow modes are assumed to be $5 \mathrm{kph}$ for walking and $15 \mathrm{kph}$ for cycling. Toll costs do not apply for commute trips in the rural WBR, as no trips would have incurred a toll in this region at the time of the census in 2006. Toll trips in the DMR are averaged at $€ 0.23$ per trip (NTA, 2010). These cost equations include for $\mathrm{CO}_{2}$ in the post-PCTS price of travel (P2). The price of $\mathrm{CO}_{2}$ per trip is determined using market values. Post-PCTS travel costs are determined using pre-PCTS cost equations (Equations 1-7) and adding the monetary cost of $\mathrm{CO}_{2}$. That is:

$$
\text { Post Costs }=\text { Pre Costs }+\mathrm{PCO}_{2}
$$

Pre-costs are the travel costs calculated for the various modes and travel times and $\mathrm{PCO}_{2}$ is European Union Allowances market $\mathrm{CO}_{2}$ price (Pointcarbon, 2011). This price is varied to investigate any welfare changes in the event of a fluctuating market price. The results for the travel cost calculations are presented in Table 3. As each individual is given an equal quota of $\mathrm{CO}_{2}$ permits in a PTCS, individuals under the quota can theoretically reduce their travel costs by selling their surplus permits. This opportunity cost is included for in the calculation of post-PCTS travel costs and subsequent welfare changes. This free allocation of permits acts as a compensation mechanism to individuals who use more sustainable forms of transport. The higher the price of $\mathrm{CO}_{2}$, the greater the potential monetary benefits to individuals holding surplus permits.

In Table 4 travel cost for private vehicles are found to be higher in the WBR at $€ 8.33$ per trip compared to $€ 7.44$ in Dublin. Public transport trips on average cost more in Dublin (€6.92) than in the WBR (€6.38). Once the cost of carbon is applied average trip costs decrease for public transport trips across each $\mathrm{CO}_{2}$ price scenario with the largest saving in the high $\mathrm{CO}_{2}$ price scenario. This is due to the inbuilt compensation mechanism discussed above in the calculation the pre-PCTS and post-PCTS costs. Individuals travelling by slow modes and public transport are likely to retain a surplus allocation of permits and thus benefit from selling this surplus in the market. This is reflected in the reduced costs observed in the medium and high price scenarios in Table 4. Private vehicle trip costs remain constant in each scenario in the WBR except for the high $\mathrm{CO}_{2}$ price scenario where a marginal increase of $€ 0.01$ occurs. In Dublin, private vehicle costs fall in the medium and high carbon price scenarios. Overall, prices in each scenario are higher in the WBR than the national average. This is also the case in the majority of scenarios in Dublin with public transport trips being the exception. These trips are found to be more expensive nationally then in either study region. 


\section{Table 4: Average travel costs}

\section{Measuring Consumer Surplus Change}

In determining any welfare loss to commuters a consumer surplus analysis is used. Consumer surplus measures the difference between what a consumer is willing to pay and what is actually paid for a good. If the price that is paid is below what an individual was willing to pay, the individual attain a consumer surplus. For a more detailed description on consumer surplus see Harberger (1971) Willig (1976) or Slesnick (1998).

Using consumer surplus is a useful tool in measuring the change in welfare as opposed to welfare levels before or after a change in market conditions. Using price levels before and after the policy is introduced, the relative change in welfare can be determined using a consumer surplus analysis as a proxy for welfare changes to compare across various socio-economic groups.

As the varying factor between the pre-PCTS and post-PCTS travel cost is the $\mathrm{CO}_{2}$ price, individuals who maintain a surplus of $\mathrm{CO}_{2}$ permits within will experience an increase in consumer and a welfare gain. Individuals with a deficit of $\mathrm{CO}_{2}$ permits within the market will experience a CS decrease and welfare loss (and produce a negative coefficient). The equation to calculate the change in consumer surplus $(\triangle \mathrm{CS})$ is as follows:

$$
\Delta C S=\frac{P_{1} G_{i}}{1+\beta_{P i}}\left\{1-\left(\frac{P_{2 i}}{P_{1}}\right)^{1+\beta_{P i}}\right\}
$$

$\mathrm{P}_{1}$ is the pre-policy price of travel and $\mathrm{P}_{2 \mathrm{i}}$ are the post-policy prices. $\beta_{\mathrm{Pi}}$ is the price elasticity of demand for travel and $\mathrm{G}_{\mathrm{i}}$ is the consumption of $\mathrm{CO}_{2}$. If consumer surplus is found to be a negative, a welfare loss has occurred and vice versa. Zero represents no change in welfare. The size of the numeric figure found is the magnitude of the change in purchasing power for travel of the individual. Since permits in a PCTS scheme are allocated freely, the opportunity cost of selling surplus permits to the market is also reflected in consumer surplus changes. Individuals using more sustainable forms of transport can benefit to a greater extent than those who use less sustainable forms of transport by selling excess permits. McNamara and Caulfield (2011b) also used this approach to determine the impacts of deprivation and density on changes in consumer surplus as a result of a PCTS. One of the assumptions of this analysis is that those with excess permits will sell these permits and enjoy their consumer surplus. This is an area that warrants further research, but for the purposes of the research presented in this paper the authors have assumed that individuals are rational utility maximises and will sell these excess papers.

\section{Descriptive Statistics for the Welfare Model}

Table 5 list the descriptive statistics for the national welfare model and both study regions in each $\mathrm{CO}_{2}$ price scenario. In the low $\mathrm{CO}_{2}$ price scenario presented in Table 5, welfare effects are found to be minimal. Nationally, average consumer surplus losses are found to be -0.02 , rising to -0.03 in the WBR. Dublin experiences a consumer surplus gain of 0.01 on average. In the medium $\mathrm{CO}_{2}$ price scenario the results diverge more between the regions. Nationally, the change in consumer surplus and consequently welfare is marginally negative with a mean value -0.04. In Dublin, the introduction of the cap has negligible effects on welfare with a mean consumer surplus change of zero. In the WBR the mean consumer surplus change is 0.05 , which is greater than the national average. In the high price scenario loses nationally 
increase to -0.07 nationally and -0.09 in the WBR. In contrast Dublin falls slightly to zero with high price scenario indicating a negligible overall welfare changes in the region.

Table 5: Consumer surplus results

\section{Spatial Distribution of Welfare Changes}

As the census dataset also provides unique geographical codes for each individual, the results can be transposed geographically using GIS software. This provides an additional layer of results as a means of comparing welfare changes across the study regions. Aggregated consumer surplus changes are calculated for over 3,400 electoral division's in each $\mathrm{CO}_{2}$ price scenario and presented in this section. Electoral division's coloured coded as dark blue experience aggregate welfare gains from the introduction of a PCTS, while electoral division's colour coded light blue and green experience small welfare losses. Electoral division's colour coded yellow, orange and red experience the largest welfare losses.

In the low $\mathrm{CO}_{2}$ price scenario illustrated in Figure 2, losses are minimal across the country. The largest losses of any occur in the WBR, Midlands and Dublin commuter belt regions. Looking at the study regions more closely reveals contrasting welfare changes between Dublin and WBR. Figure 3 shows the majority of electoral division's in WBR experience an aggregate loss, albeit a minimal loss represented by electoral division's colour coded light blue. A small minority of isolated rural electoral division's experience larger losses coloured coded orange and yellow. The Dublin region in contrast experiences an aggregate welfare gain in Figure 4. The vast majority of electoral division's in the region experience a gain aside from a number of electoral division's in the north of the region which experience a marginal loss.

Figure 2: National consumer surplus change (Low $\mathrm{CO}_{2}$ price - €8.24)

Figure 3: WBR consumer surplus change (Low $\mathrm{CO}_{2}$ price - €8.24)

Figure 4: Dublin consumer surplus change (Low $\mathrm{CO}_{2}$ price - $\left.€ 8.24\right)$

In the medium price scenario, considerable differences in welfare changes are evident nationally and in the WBR compared to the low price scenario. Figure 5 illustrates the regions experiencing the largest losses are rural regions in the WBR and the Dublin commuter belt. Figure 5 shows larger welfare losses occurring in electoral division's greater distances from urban centres in the WBR. Welfare changes in Dublin (Figure 7) remain as they were observed in Figure 3, with the vast majority of electoral division's in the region experiencing an aggregate welfare gain excluding a number of E electoral division's in the north of the county which experience marginal losses.

Figure 5: National consumer surplus change (Medium $\mathrm{CO}_{2}$ price - €16.70)

Figure 6: WBR consumer surplus change (Medium $\mathrm{CO}_{2}$ price- $\left.€ 16.70\right)$

Figure 7: Dublin consumer surplus change (Medium $\mathrm{CO}_{2}$ price - €16.70) 
Figures 8 to 10 illustrate a clear outcome of larger welfare losses in electoral divisions farther from major urban centres in a high $\mathrm{CO}_{2}$ price scenario. Electoral division's encompassing the major urban centres of is found to have welfare gains with the advent of a PCTS. A pattern of concentric rings around these urban centres is also visible in each figure as welfare gains convert into losses the greater the distance from urban centres. Figure 10 again shows no change in welfare in Dublin compared to the low and medium price scenarios save for the aforementioned electoral division's in the north of the county which experience marginal welfare losses.

Figure 8: National consumer surplus change (High $\mathrm{CO}_{2}$ price - €28.73)

Figure 9: WBR consumer surplus change (High $\mathrm{CO}_{2}$ price - €28.73)

Figure 10: Dublin consumer surplus change $\left(\right.$ High $\mathrm{CO}_{2}$ price - €28.73)

This GIS analysis confirms the urban-rural divide in the welfare results. Dublin is found to experience a welfare gain on aggregate in a PCTS under all $\mathrm{CO}_{2}$ price scenarios, while large swaths of the WBR experience aggregate losses in each scenario.

\section{Socio-economic analysis of welfare results}

This analysis will model for four welfare outcomes using MNL models. Welfare changes for the dependent variable are categorised as 'positive' or 'negative' in the model under four categories detailed in Table 6 . These welfare changes, measured by changes in consumer surplus, are then regressed on a number of socio-economic variables to determine the factors that contribute to individuals having a negative or positive change in consumer surplus and consequently welfare.

\section{Table 6: Details of consumer surplus variable}

\section{Multinomial Logit Regression Model Formulation}

Six models are estimated in this section; a national, a Dublin and a WBR model, each with a low, medium and high $\mathrm{CO}_{2}$ price scenario. Five variables are chosen as independent variables in the model. The age, gender, socio-economic group, household and residential density are examined in the MNL models. The constituent groups of these variables are detailed in Table 7. The dependent variable categories are 'large negative change', 'marginal negative change' and 'marginal positive change'. The reference category is the 'positive change'. The outcomes for the dependent variable are predicted vis-à-vis the reference category 'positive change' as defined in Table 7.

The MNL model takes the following functional form. Consider an event $\mathrm{Y}$, which in this case is an individual emitting $\mathrm{CO}_{2}$ above a predetermined cap. The probability of a person being above this cap is $\mathrm{P}(\mathrm{Y})$ in the model and the resulting outcome is equal to one. The dependent variable is the log of the odds ratio of the event $\mathrm{Y}$ occurring or the logit of $\mathrm{Y}$. That is:

$$
\operatorname{Logit}(\mathrm{Y})=\ln \left(\frac{\hat{Y}}{1-\hat{Y}}\right)=\beta_{0}+\beta_{i} \cdot X_{i}
$$

$\beta_{0}$ is the model constant and $\beta_{\mathrm{i}}$ are the parameter estimates for the set of socioeconomic 
independent variables $\left(X_{i}, i=1, \ldots, \mathrm{n}\right) . \hat{Y}$ is the predicted probability of the event which takes binary values of 1 (continue analysis) or 0 (stop the analysis).

\section{Table 7: Details of variables examined}

\section{MNL Regression Results in a Low $\mathrm{CO}_{2}$ Price Scenario}

The results presented in Tables 8 to 10 are estimated for the national, Dublin and WBR datasets based on a low $\mathrm{CO}_{2}$ price scenario of $€ 8.24$. The reference category in all cases is a 'positive change' in consumer surplus and all outcomes are predicted vis-à-vis this category. The performance of each model shows the national model to be the best fitted model. Rsquared value for the national model of 0.16 is the largest of the three models The Dublin and WBR datasets yield R-squared values of 0.043 and 0.86 respectively. The WBR model does yields the lowest log-likelihood despite the lower R-squared value observed.

The age category has a significant effect on the outcomes of having a large negative change (LNC) and a marginal negative change (MNC) in comparison to having a positive change both nationally, in the WBR and to a lesser extent in Dublin. Nationally the groups most likely to have a LNC are younger age groups particularly the 25-44 age group. This is also the case in the WBR. The Dublin model returns lower beta coefficient for all groups and all are insignificant outside of the aforementioned 25-44 group. This age group is also likely to experience a MNC and marginal positive change (MPC) nationally and in Dublin. All age groups with a positive welfare change in the WBR are insignificant in the model as the previous sections have shown very few individuals experience a welfare gain in this region in any scenario. The number of cases therefore is not sufficient to merit statistical significance. In terms of gender, the odds of having a LNC as opposed to positive welfare change are increased by being male in all three datasets, particularly in the WBR. This is also the case for individuals having a MNC in Dublin and the WBR. Individuals with a MPC are more likely to be females in all three models.

The results for the socio-economic variable are less conclusive. Many categories within this variable are likely to have both positive and negative consumer surplus changes. Employers and managers and higher and lower professionals are the only groups likely to have a LNC and a MNC across all three models. This may be due to higher income levels within these groups and the use of less sustainable modes of transport. Semi skilled and unskilled groups are unlikely to have a negative change in the national and WBR models, but are in Dublin. However, these groups are also unlikely to have a positive change yielding an inconclusive result. Farmers and agricultural worker are unlikely to have a negative change in consumer surplus across each model except in Dublin where they are likely to have a MNC.

For the household composition variable, couples with dependent children and are more likely to have a negative consumer surplus change than single or lone parents in all three models. Couples with no children also have a large beta coefficient in the negative change categories indicating more of likelihood of this outcome than having a positive change. The density variable yields more conclusive results. Large beta coefficients across all three models are found for individuals living in sparsely populated electoral division's indicating a likelihood of individuals in these areas having a negative consumer surplus change. These individuals are also unlikely to have a positive change in Dublin and the WBR. Individuals living in electoral divisions with a density of population of more than 1,000 persons per $\mathrm{km}^{2}$ are less likely to have a negative consumer surplus change. Due to the high statistical significance and relatively large coefficients it can be postulated that density of population explains much of the variation in consumer surplus changes found in this analysis. 
Table 8: MNL model results (National Dataset: Low $\mathrm{CO}_{2}$ price - €8.24)

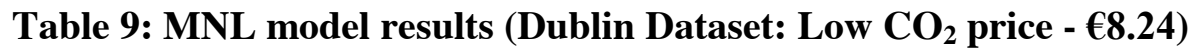

Table 10: MNL model results (WBR Dataset: $L$ ow $\mathrm{CO}_{2}$ price - €8.24)

MNL Regression Results in a Medium $\mathrm{CO}_{2}$ Price Scenario

This section presents the MNL model results for the medium $\mathrm{CO}_{2}$ price scenario of $€ 16.70$.

Tables 11 to 13 detail the findings of the MNL for the national, Dublin and WBR datasets. Model performance is improved on the low $\mathrm{CO}_{2}$ price model. R-squared values increase to 0.13 for the national dataset, but remain static at 0.043 and 0.086 for the Dublin and WBR models respectively. The WBR model maintains the smallest log likelihood value.

For the age variable, as was the case in the low $\mathrm{CO}_{2}$ price scenario, age groups ranging from 25-44 are most likely to have a negative consumer surplus change. However, this is not the case in Dublin where all but one of the outcomes for the LNC was found to be insignificant. The gender variable follows the same trend as was observed in the low $\mathrm{CO}_{2}$ price scenario with males being more likely to have a negative consumer surplus change than females. Females are also more likely to have a positive consumer surplus change than males across all three models.

Socio-economic groupings again yield inconclusive results beta coefficients smaller than those observed in the low $\mathrm{CO}_{2}$ price scenario. Nationally and in the WBR, farmers and agricultural workers are the most likely groups to avoid having a negative consumer surplus change. The likelihood of employers, managers and professionals having a LNC also falls in comparison to the low price scenario in all three models. No group is likely to have a positive consumer surplus change nationally or in the WBR. Manual skilled workers are the only group likely to have a positive consumer surplus change in Dublin. However, this result is statistically insignificant and therefore inconclusive.

The household composition variable returns more conclusive results than in the low $\mathrm{CO}_{2}$ scenario. Nationally and in the WBR, all groups in this variable are likely to be to have a negative change (LNC and MNC). However, individuals living in Dublin have a much smaller likelihood of having a LNC. Couples with dependent children in Dublin are also marginally unlikely to have a positive welfare change. Nationally and in the WBR, individuals with dependent children are the likeliest group to have a positive welfare change. However the associated coefficients are smaller than those observed in the Dublin dataset. Single individuals are likely to have a positive change. In Dublin, single individuals with a positive consumer surplus change and are more likely to have positive welfare change than a MPC. The results indicate that individuals with dependent families are more likely to experience welfare losses. Again the density variable is highly significant across all three models confirming the importance of population density in explaining welfare losses.

Table 11: MNL model results (National Dataset: Medium $\mathrm{CO}_{2}$ price - $€ 16.70$ )

Table 12: MNL model results (Dublin Dataset: Medium $\mathrm{CO}_{2}$ price - €16.70)

Table 13: MNL model results (WBR Dataset: Medium $\mathrm{CO}_{2}$ price - $€ 16.70$ ) 
Regression Results in a High $\mathrm{CO}_{2}$ Price Scenario

This section presents the MNL model results for the high $\mathrm{CO}_{2}$ price scenario of $€ 28.73$. The MNL model results for this scenario are presented f§or the national, Dublin and WBR datasets in Tables 14 to 16 respectively. Model performance improves from previous models with R-squared values of $0.115,0.089$ and 0.155 for the national, Dublin and WBR models. The WBR model maintains the lowest log-likelihood value.

The age category again indicates younger age groups to be more likely to have a negative change in all three models. This is the case for 25-44 year old groups in Dublin and the national model. In the WBR, 15-24 year olds are more likely to have a negative change than older age groups. Older individuals are also more likely to have a positive change in consumer surplus across all three models. 55-64 and 65+ age groups are more likely to have a positive change than other outcomes particularly in the national dataset. The likelihood of males having a negative consumer surplus change is also observed in this scenario. In all three models males are more likely to have both a LNC and a MNC than females. Females are also more likely to have a MPC than males.

Socio-economic group results do not vary greatly from the other two scenarios. Nationally and in the WBR, farmers and agricultural workers are the most likely groups to not have a negative consumer surplus change. This is not the case in Dublin where farmers are the most likely group to have a LNC. The likelihood of employers, managers and professionals having a LNC also falls in comparison to the low and medium price scenarios in all three models. As was observed in the previous scenarios, non-manual, semi-skilled and unskilled workers are unlikely to have a LNC across all three models with these grouping more likely to have a positive consumer surplus change.

In all three models, household composition is found to be a significant factor in determining welfare changes. The only exception to this is in Dublin where this variable is found to be insignificant in explaining a LNC. All groups are likely to have a MNC across all three models. In terms of having a positive consumer surplus change, all groups are unlikely to have this outcome particularly couples with dependent children.

While the coefficients associated with the density variable are not as large as the low and medium $\mathrm{CO}_{2}$ price scenarios, relatively larger beta coefficients in comparison to other independent variables are found for the density variable. Across all three models individuals living in electoral division's with less than 50 persons per $\mathrm{km}^{2}$ are more likely to have a negative consumer surplus change. Individuals with a positive welfare change are also more likely to live in densely populated electoral divisions than those in sparsely populated electoral divisions. Density is the most significant determinant of welfare changes in the high $\mathrm{CO}_{2}$ price scenario.

Table 14: MNL model results (National Dataset: High $\mathrm{CO}_{2}$ price - €28.73)

Table 15: MNL model results (Dublin Dataset: High $\mathrm{CO}_{2}$ price - €28.73)

Table 16: MNL model results (WBR Dataset: $\mathrm{High} \mathrm{CO}_{2}$ price - €28.73)

The MNL models confirm that density of population is an important factor in explaining the determinants of welfare changes. The gender variable consistently found males to be more likely to have larger welfare losses than female in all three scenarios, while individuals with dependent children were found to be likely to experience larger welfare losses. Individuals 
aged between 25 and 44 were also consistently the most likely individuals to have a negative welfare change. This result is expected in a dataset detailing commute trip as the bulk of the workforce is drawn from this age group. Socio-economic grouping was mostly inconclusive in each scenario, with only non-manual and unskilled workers the most likely individuals to have a positive welfare change in all scenarios. Employers and managers, higher professionals and lower professionals were also consistently likely to have negative changes in welfare in each scenario. Beta coefficients for individuals likely to have negative changes were also consistently higher in the WBR compared to Dublin, indicating a greater likelihood of losses in the rural region.

\section{Impact of the research conducted}

The research presented in this paper contributes the field of research in determining the welfare outcomes of introducing a PCTS. This type of analysis had not been previously completed using logistic regression techniques. Segmenting the analysis across socioeconomic groups and regions further strengthens the contribution to knowledge in using this modeling technique. The use of a MNL model in determining the characteristics of individuals with negative and positive welfare changes is also a contribution to the knowledge in observing the socio-economic effects of a PCTS.

While studies have been conducted to determine the welfare effects of carbon trading, this paper focused on identifying any divergences in welfare changes between urban and rural regions. The divergences observed in the results highlight the importance of comparing the effects of the policy in both regions and validate the research objective to study this aspect of a PCTS outcome.

The results presented in this paper also have a number of practical policy implications. The findings of inequity for individuals in rural regions would necessitate a heterogeneous structure of a PCTS scheme to remedy theses potential outcome. This could involve an increase of $\mathrm{CO}_{2}$ permit allocations for individuals constrained to using private vehicles as their primary form of transport in rural regions. A price ceiling on $\mathrm{CO} 2$ within the market for these vulnerable socio- economic groups could also provide a mechanism to ensure more equitable welfare outcomes. A final measure to alleviate the burden on these groups would be to incentivize and/or subsidise the purchase or environmentally friendly electric or hybrid vehicles in rural regions where public transport alternatives are not a viable alternative. This paper identified the equity problems and ambiguous environmental dividend associated with existing carbon reduction measures such as carbon taxation and upstream trading. Therefore, there is a necessity for further investigation of a downstream type scheme as an alternative policy.

\section{Conclusions}

The findings presented in this paper show that those in the WBR region experienced a larger welfare loss than the Dublin region. This analysis studied welfare changes in three market scenarios of a low medium and high $\mathrm{CO}_{2}$ price. A consumer surplus analysis was used as a proxy for welfare changes. Consumer surplus changes were based on a comparison between travel costs before and after the introduction of a PCTS. An addition of a $\mathrm{CO}_{2}$ price into individual trips caused a negative welfare change for individuals using carbon-intensive modes of transport and a positive welfare change for individuals using more sustainable modes of transport, particularly those who walk and cycle to work. The inbuilt equity of the 
scheme whereby an individual with a surplus could theoretically benefit from selling excess permits was reflected in the results. Walking, cycling and public transport trips were found to generally reduce in cost with the introduction of a scheme. The higher the $\mathrm{CO}_{2}$ price, the greater the benefit derived by individuals with excess permits was the key finding of this section. The opposite was true for individuals using private vehicles to travel to work, particularly in the WBR. Travel costs increased in the medium and high $\mathrm{CO}_{2}$ price scenarios for these individuals in the WBR, but remained static for individuals in Dublin. This can be attributed to the shorter travel distances in Dublin than the WBR. Mapping the welfare changes using GIS across each electoral division also confirmed the largest losses occur in rural regions greater distances from major urban centres.

A further socio-economic analysis using a MNL model compared the socio-economic characteristics of individuals having a positive or negative welfare change. This analysis confirmed that density of population was the major determinant of welfare changes as individuals living in more sparsely populated areas were more likely to experience a negative welfare change. Parameter coefficients associated with the density variable were significantly larger than other independent variables included in the model. Deprivation levels were not as statistically significant as density levels in Dublin or the national results but were of marginal significance in determining negative welfare changes in the WBR. As was the case with the BLR model results, individuals in the 25 to 44 year old age groups were likely to have a negative welfare change. Males were also more likely to have a larger negative welfare change than females possibly due to the higher percentage of males in the workforce in the dataset.

\section{Acknowledgements}

The authors would like to thank the Central Statistics Office of Ireland and the National Transport Authority for providing the data for this study.

\section{References}

AGRAWAL, A. W., DILL, J. \& NIXON, H. 2010. Green transportation taxes and fees: A survey of public preferences in California. Transportation Research Part D: Transport and Environment, 15, 189-196

BRistOW, A. L., WARDMAN, M., ZANNI, A. M. \& CHINTAKAYALA, P. K. 2010. Public acceptability of personal carbon trading and carbon tax. Ecological Economics, 69, 1824-1837

BAUMOL, W. J. 1972. On Taxation and the Control of Externalities. The American Economic Review, 62, 307-322

CALLAN, T., LYONS, S., SCOTT, S., TOL, R. S. J. \& VERDE, S. 2009. The distributional implications of a carbon tax in Ireland. Energy Policy, 37, 407-412

CSO, 2006. Census of Population of Ireland 2006 Place of Work Census of Anonymised Records (POWCAR) User Guide. In: OFFICE, C. S. (ed.). Dublin, Ireland

CSO, 2011. The Preliminary Report for Census 2011. In: OFFICE, C. S. (ed.). Dublin, Ireland 
EKINS, P. \& DRESNER, S. 2004. Green taxes and charges: reducing their impact on lowincome households. Joseph Rowntree Foundation, York

EPA 2010. Ireland's Greenhouse Gas Emissions 2009. Dublin: Environmental Protection Agency

PIGOU, A. C. 1952. The economics of welfare, Transaction Publishers

GOULDER, L. H. 1995. Environmental taxation and the double dividend: A reader's guide. International Tax and Public Finance, 2, 157-183.

HARBERGER, A. C. 1971. Three basic postulates for applied welfare economics: an interpretive essay. Journal of Economic literature, 9, 785-797

MCNAMARA, D., CAULFIELD, B, Measuring the potential implications of introducing a cap and share scheme in Ireland to reduce green house gas emissions, Transport Policy, 18, 2011a, p579- 586

MCNAMARA, D., CAULFIELD, B., Determining the welfare effects of introducing a capand-share scheme on rural commuters, Transportation Research Part D: Transport and Environment, 16, 2011b, p547 - 553

NTA, 2010. Greater Dublin Area: Draft Transport Strategy, 2011 - 2030. 2030 Vision. Dublin: National Transport Authority.

PEARCE, D. 1991. The Role of Carbon Taxes in Adjusting to Global Warming. The Economic Journal, 101, 938-948

POINTCARBON, 2011. Historical EUA spot prices, Dec 2011 Market. Retrieved from Pointcarbon website, June - Sept. 2011. Website: www.pointcaron.com

STEER DAVIE GLEAVE. 2009. Highway and PT Assignment Model Calibration and Validation Report. Dublin: National Transport Authority (Personal Communication)

SYMONS, E., PROOPS, J. \& GAY, P. 1994. Carbon taxes, consumer demand and carbon dioxide emissions: a simulation analysis for the UK. Fiscal Studies, 15, 19-43

SOVACOOL, B. K. 2010. Building Umbrellas or Arks? Three Alternatives to Carbon Credits and Offsets. The Electricity Journal, 23, 29-40

SLESNICK, D. T. 1998. Empirical Approaches to the Measurement of Welfare. Journal of Economic literature, 36, 2108-2165

WILLIG, R. D. 1976. Consumer's Surplus Without Apology. The American Economic Review, 66, 589-597. 


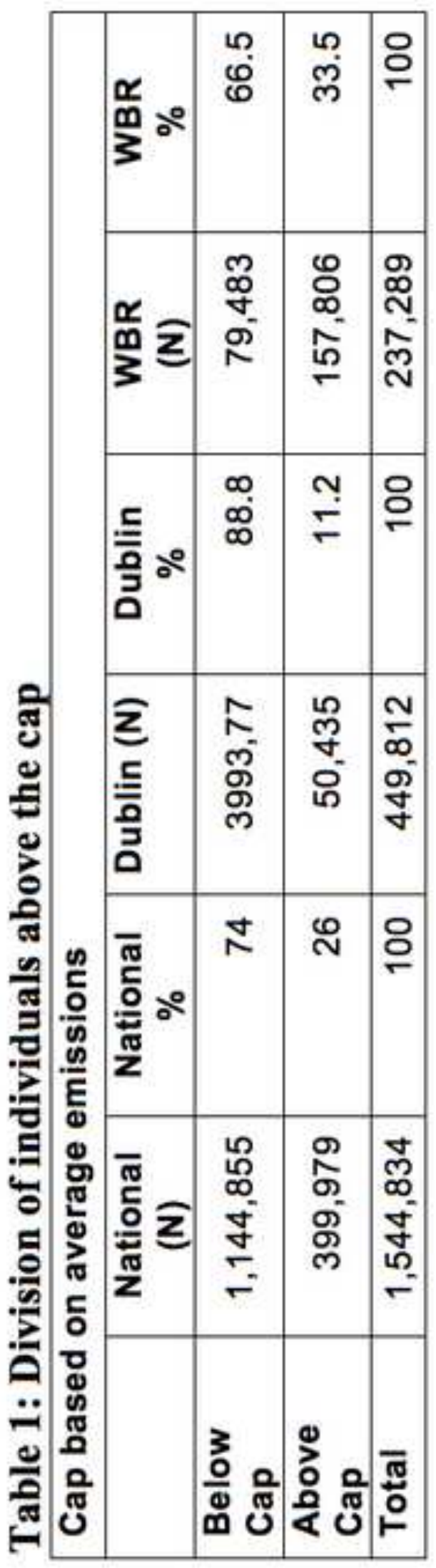

-

응 은 


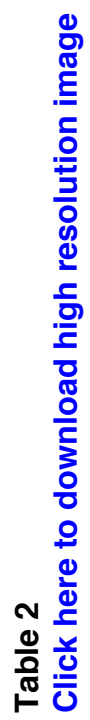

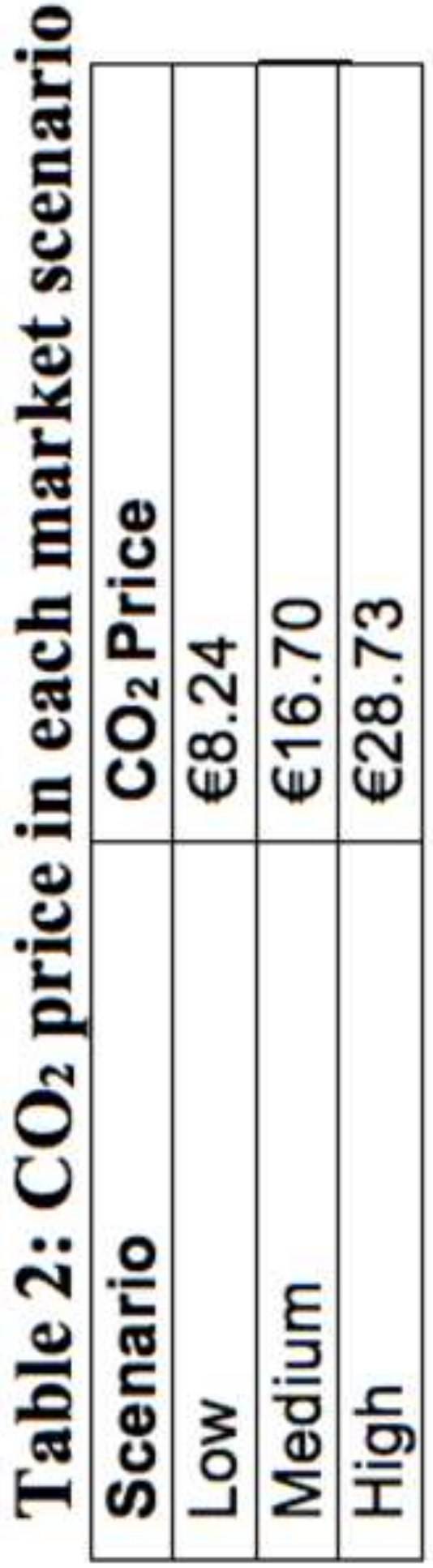




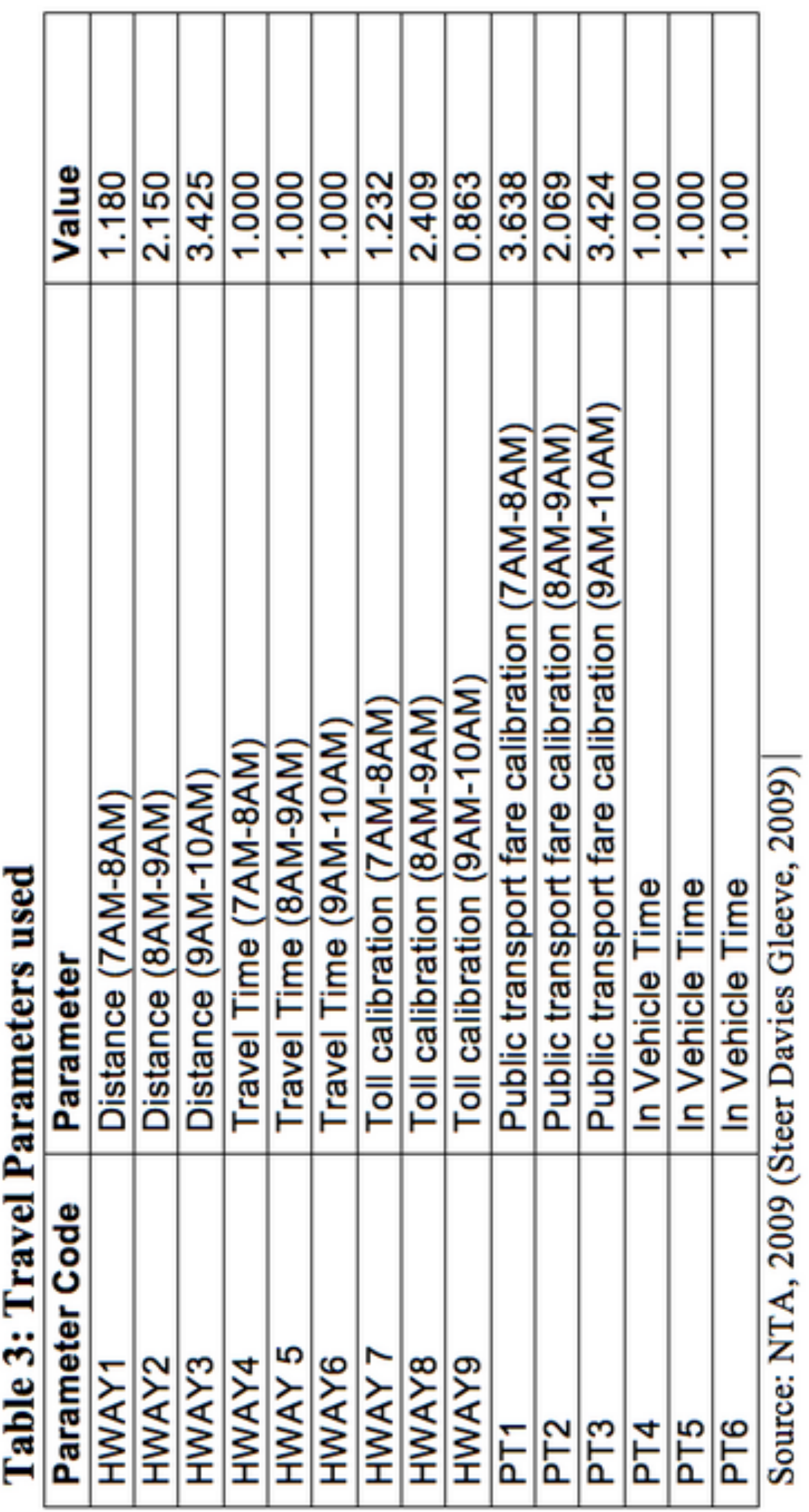

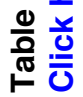




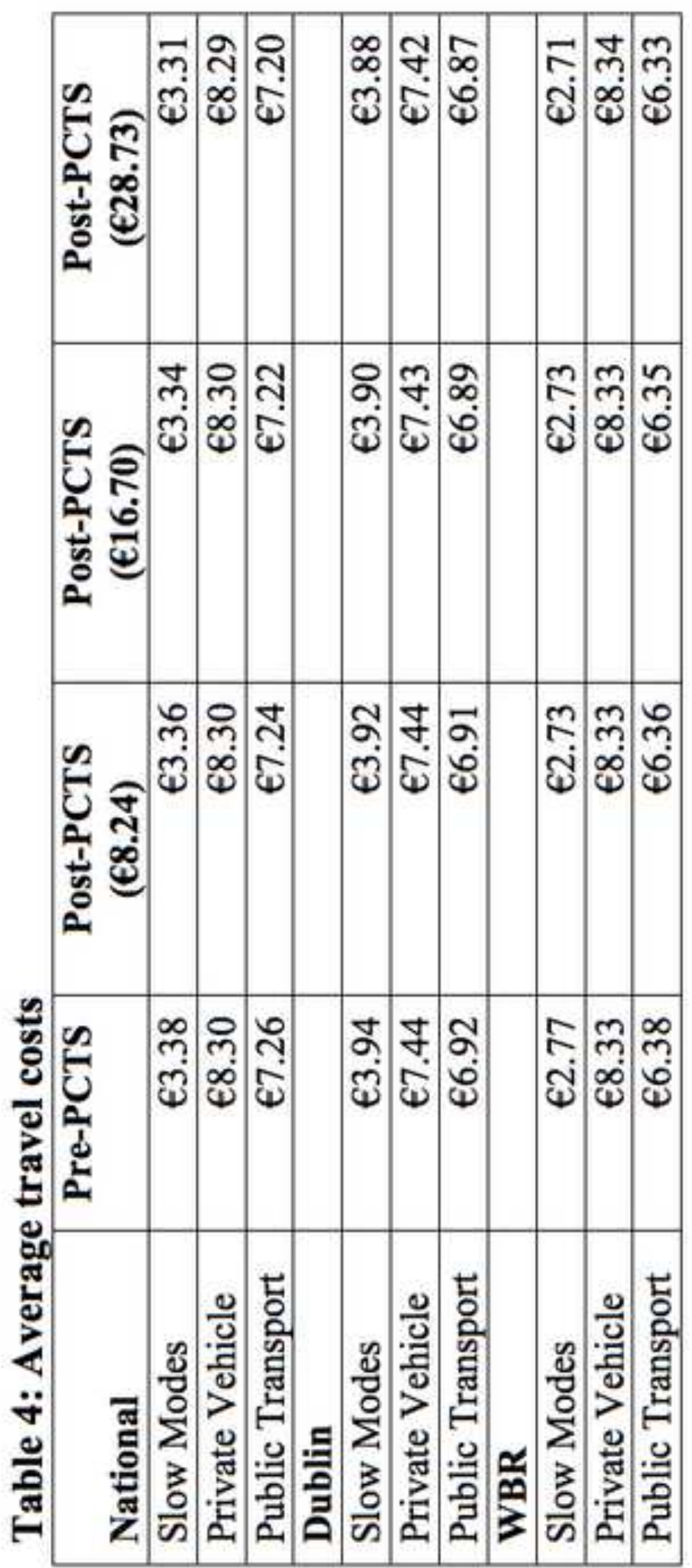

$\forall \stackrel{0}{ }$

虽产 


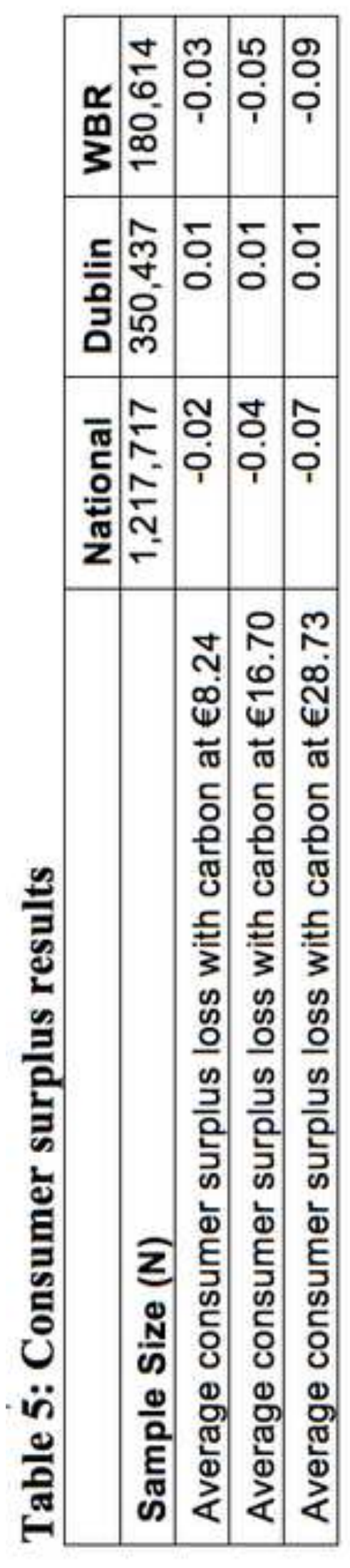

10

은 은 


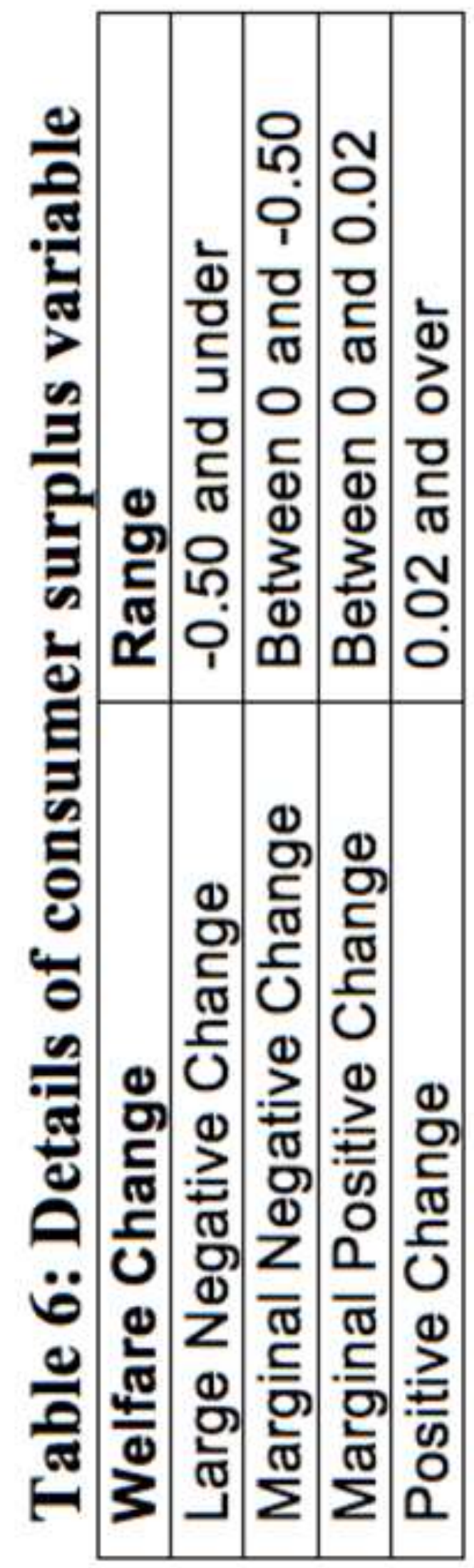

$0 \stackrel{\frac{2}{d}}{\frac{1}{2}}$

遂啇 
Table 7

Click here to download high resolution image

Table 7: Details of variables examined

\begin{tabular}{|c|c|}
\hline Variable & Definition \\
\hline \multicolumn{2}{|l|}{ Age } \\
\hline $15-24$ & $=1$ if Age: $15-24$ \\
\hline $25-34$ & $=1$ if Age: $25-34$ \\
\hline $35-44$ & $=1$ if Age: $35-44$ \\
\hline $45-54$ & $=1$ if Age: $45-54$ \\
\hline $55-64$ & $=1$ if $\mathrm{Age}: 55-64$ \\
\hline $65+$ & (Reference category $=65+$ ) \\
\hline \multicolumn{2}{|l|}{ Gender } \\
\hline Gender: Male & $=1$ if Gender: male \\
\hline Gender: Female & (Reference category = Gender: Female) \\
\hline \multicolumn{2}{|l|}{ Socio-economic group } \\
\hline Employers and managers & $=1$ if Employers and managers \\
\hline Higher professional & $=1$ if Higher professional \\
\hline Lower professional & $=1$ if Lower professional \\
\hline Non-manual & $=1$ if Non-manual \\
\hline Manual skilled & $=1$ if Manual skilled \\
\hline Semi skilled & $=1$ if Semi skilled \\
\hline Unskilled & $=1$ if Unskilled \\
\hline Self employed & $=1$ if Self employed \\
\hline Farmers & $=1$ if Farmers \\
\hline Agricultural workers & $=1$ if Agricultural work \\
\hline Other & (Reference category $=$ Other) \\
\hline \multicolumn{2}{|l|}{ Household Composition } \\
\hline Single & $=1$ if Single \\
\hline Lone Parent with Children & $=1$ if Lone Parent with Children \\
\hline Lone Parent no Children under 19 & $=1$ if Lone Parent no Children under 19 \\
\hline Couple with Children & $=1$ if Couple with Children \\
\hline Couple no Children under 19 & $=1$ if Couple no Children under 19 \\
\hline Couple no Children & $=1$ if Couple no Children \\
\hline Other Households & (Reference category = Other Households) \\
\hline \multicolumn{2}{|l|}{ Density per $\mathrm{km}^{2}$} \\
\hline $0-50$ persons & $=1$ if $0-50$ persons \\
\hline $50-250$ persons & $=1$ if $50-250$ persons \\
\hline $250-1,000$ persons & $=1$ if $250-1000$ persons \\
\hline $1,000-5,000$ persons & $=1$ if $1,000-5,000$ persons \\
\hline $5,000+$ persons & (Reference category $=5000+$ persons) \\
\hline
\end{tabular}


Table 8

Click here to download high resolution image

Table 8: MNL model results (National Dataset: Low $\mathrm{CO}_{2}$ price - $€ 8.24$ )

\begin{tabular}{|c|c|c|c|}
\hline Variable & $\begin{array}{c}\text { Large } \\
\text { negative change }\end{array}$ & $\begin{array}{c}\text { Marginal } \\
\text { negative change }\end{array}$ & $\begin{array}{c}\text { Marginal } \\
\text { positive change }\end{array}$ \\
\hline Intercept & $-4.223^{* *}$ & .060 & $4.979^{* *}$ \\
\hline \multicolumn{4}{|l|}{ Age } \\
\hline $15-24$ & $1.089^{* *}$ & $1.128^{* *}$ & $.567^{* *}$ \\
\hline $25-34$ & $1.615^{* *}$ & $1,428^{* *}$ & $.483^{* *}$ \\
\hline 35.44 & $1.541^{* *}$ & $1.407^{* *}$ & $.578^{* *}$ \\
\hline $45-54$ & $.978^{* *}$ & $1.014^{* *}$ & $436^{* *}$ \\
\hline $55-64$ & .373 & $.529^{* *}$ & $.202^{* *}$ \\
\hline $65+$ & Ref & Ref & Ref \\
\hline \multicolumn{4}{|l|}{ Gender } \\
\hline Male & $.195^{* *}$ & $-.549^{* *}$ & $-.911^{* *}$ \\
\hline Female & Ref & Ref & Ref \\
\hline \multirow{2}{*}{\multicolumn{4}{|c|}{ Socio-economic group }} \\
\hline & & & \\
\hline Employers and managers & $1.501^{* *}$ & $1.331^{* *}$ & $940^{* *}$ \\
\hline Higher professional & $1.220^{* *}$ & $1.010^{* *}$ & $.501^{* *}$ \\
\hline Lower professional & $1.014^{*}$ & $1.031^{* *}$ & $.477^{*}$ \\
\hline Non-manual & $.237^{*}$ & $.361^{* *}$ & $.320^{* *}$ \\
\hline Manual skilled & $.473^{* *}$ & $.594^{* *}$ & $309^{* *}$ \\
\hline Semi skilled & $-.784^{* *}$ & $-.378^{* *}$ & $-.311^{*}$ \\
\hline Unskilled & $-.506^{* *}$ & $-.320^{* *}$ & $-.197^{*}$ \\
\hline Self employed & $1.362^{* *}$ & $1.157^{* *}$ & $.841^{* *}$ \\
\hline Farmers & $-1.664^{* *}$ & $-1.088^{* *}$ & -.217 \\
\hline Agricultural workers & $-1.963^{* *}$ & $-1.369 * *$ & $-.744^{* *}$ \\
\hline Other & Ref & Ref & Ref \\
\hline \multicolumn{4}{|l|}{ Household Composition } \\
\hline Single & $.788^{* *}$ & $.567^{* *}$ & .078 \\
\hline Lone Parent with Children & $.714^{* *}$ & $.685^{* *}$ & $.445^{* *}$ \\
\hline Lone Parent no Children under 19 & $457^{* *}$ & $.527^{* *}$ & .144 \\
\hline Couple with Children & $1.058^{* *}$ & $.976 *$ & $.484^{* *}$ \\
\hline Couple no Children under 19 & $1.013^{* *}$ & $.946^{* *}$ & $.524^{* *}$ \\
\hline Couple no Children & $1.169^{* *}$ & $.984^{* *}$ & $.312^{* *}$ \\
\hline Other Households & Ref & Ref & Ref \\
\hline \multicolumn{4}{|l|}{ Density per $\mathrm{km}^{2}$} \\
\hline 0.50 persons & $3.858^{* *}$ & $3.378^{* *}$ & $1.363^{* *}$ \\
\hline $50-250$ persons & $2.871^{* *}$ & $2.477^{* *}$ & $.753^{* *}$ \\
\hline $250-1,000$ persons & $2.278^{* *}$ & $1.655^{* *}$ & $.263^{* *}$ \\
\hline $1,000-5,000$ persons & $1.393^{* *}$ & $1.061^{* *}$ & $.286^{* *}$ \\
\hline $5,000+$ persons & Ref & Ref & Ref \\
\hline Number of Cases & \multicolumn{3}{|c|}{$1,212,306$} \\
\hline Nagelkerke R-squared & \multicolumn{3}{|c|}{.160} \\
\hline Log Likelihood & \multicolumn{3}{|c|}{118183.763} \\
\hline
\end{tabular}

** Significant at $1 \%,{ }^{*}$ Significant at $5 \%$ 
Table 9

Click here to download high resolution image

Table 9: MNL model results (Dublin Dataset: Low $\mathrm{CO}_{2}$ price - $€ 8.24$ )

\begin{tabular}{|c|c|c|c|}
\hline Variable & $\begin{array}{c}\text { Large } \\
\text { negative change }\end{array}$ & $\begin{array}{c}\text { Marginal } \\
\text { negative change }\end{array}$ & $\begin{array}{c}\text { Marginal } \\
\text { positive change }\end{array}$ \\
\hline Intercept & $-4,769^{* *}$ & $-3.453^{* *}$ & $818^{* *}$ \\
\hline \multicolumn{4}{|l|}{ Age } \\
\hline $15-24$ & -.081 & .060 & $252^{* *}$ \\
\hline $25-34$ & $297^{\circ}$ & $.370^{* *}$ & $.169 *$ \\
\hline $35-44$ & $330^{\circ}$ & $394^{* *}$ & $146^{* *}$ \\
\hline $45-54$ & .164 & $.249^{* *}$ & $.088^{\circ}$ \\
\hline $55-64$ & -.082 & .135 & .045 \\
\hline $65+$ & Ref & Ref & Ref \\
\hline & & & \\
\hline \multicolumn{4}{|l|}{ Gender } \\
\hline Male & $598^{\circ}$ & $372^{* *}$ & $-.096^{* *}$ \\
\hline Female & Ref & Ref & Ref \\
\hline \multicolumn{4}{|l|}{ Socio-economic group } \\
\hline Employers and managers & $.450^{* *}$ & $.525^{* *}$ & $132 * *$ \\
\hline Higher professional & $.389 * 0$ & $.343^{* *}$ & $114^{* *}$ \\
\hline Lower professional & .004 & $.348^{* *}$ & $.081^{* *}$ \\
\hline Non-manual & $-.364^{* *}$ & .002 & $124^{* *}$ \\
\hline Manual skilled & $.572^{* *}$ & $.648^{* *}$ & $.133^{* *}$ \\
\hline Semi skilled & -.079 & .013 & $.084^{* *}$ \\
\hline Unskilled & .037 & -.065 & $.120^{* *}$ \\
\hline Self employed & $.709^{* *}$ & $.660^{* *}$ & -.028 \\
\hline Farmers & $1.145^{* *}$ & -.214 & $-.758^{* *}$ \\
\hline Agricultural workers & .099 & -.577 & $-.592^{* *}$ \\
\hline Other & Ref & Ref & Ref \\
\hline \multicolumn{4}{|l|}{ Housohold Composition } \\
\hline Single & $.198^{* *}$ & $299^{* *}$ & .006 \\
\hline Lone Parent with Children & .150 & $.255^{* *}$ & $-.047^{\circ}$ \\
\hline Lone Parent no Children under 19 & $.291^{* 1}$ & $.437^{* *}$ & $189^{* *}$ \\
\hline Couple with Children & $.218^{* *}$ & $.501^{* *}$ & .020 \\
\hline Couple no Children under 19 & $.322^{* *}$ & $.481 * 0$ & $.147^{* *}$ \\
\hline Couple no Children & $.332 * *$ & $.509^{* *}$ & $.073^{* *}$ \\
\hline Other Households & Ref & Ref & Ref \\
\hline \multicolumn{4}{|l|}{ Density per $\mathrm{km}^{2}$} \\
\hline $0-50$ persons & $1.772^{* *}$ & $2.352^{* *}$ & $-.249^{\circ}$ \\
\hline $50-250$ persons & $.546^{\circ *}$ & $1.408^{* 0}$ & $.073^{\circ}$ \\
\hline $250-1,000$ persons & $.986^{* *}$ & $1.482^{* *}$ & $.066^{* *}$ \\
\hline $1,000-5,000$ persons & $.509 *$ & $.773^{* *}$ & $.161^{* *}$ \\
\hline $5,000+$ persons & Ref & Ref & Ref \\
\hline & \multicolumn{3}{|c|}{350,437} \\
\hline $\begin{array}{l}\text { Number of Cases } \\
\text { Nagelkerke R-squared }\end{array}$ & \multicolumn{3}{|c|}{.043} \\
\hline Log Likelihood & \multicolumn{3}{|c|}{77933.814} \\
\hline
\end{tabular}

** Significant at $1 \%,{ }^{*}$ Significant at $5 \%$ 
Table 10

Click here to download high resolution image

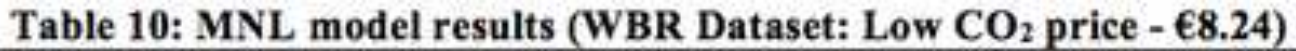

\begin{tabular}{|c|c|c|c|}
\hline Variable & $\begin{array}{l}\text { Large } \\
\text { negative change }\end{array}$ & $\begin{array}{c}\text { Marginal } \\
\text { negative change }\end{array}$ & $\begin{array}{c}\text { Marginal } \\
\text { positive change }\end{array}$ \\
\hline Intercept & $-3.158^{* *}$ & -2.679 & 1.200 \\
\hline \multicolumn{4}{|l|}{ Age } \\
\hline $15-24$ & $.972^{* *}$ & $.787^{* *}$ & .037 \\
\hline $25-34$ & $1.432^{* *}$ & $1.085^{* *}$ & .059 \\
\hline $35-44$ & $1.250^{* *}$ & $.957^{* *}$ & .101 \\
\hline $45-54$ & $.925^{* *}$ & $.835^{\circ *}$ & .164 \\
\hline $55-64$ & $.522^{* *}$ & $.560^{* *}$ & .165 \\
\hline $65+$ & Ref & Ref & Ref \\
\hline \multicolumn{4}{|l|}{ Gender } \\
\hline Male & $.420^{* *}$ & .035 & -.100 \\
\hline Female & Ref & Ref & Ref \\
\hline \multicolumn{4}{|l|}{ Socio-economic group } \\
\hline Employers and managers & $432^{* *}$ & $222^{* *}$ & -.060 \\
\hline Higher professional & $.948^{* *}$ & $.665^{* *}$ & .065 \\
\hline Lower professional & $.938^{* *}$ & $.705^{* *}$ & .021 \\
\hline Non-manual & -.040 & -.029 & $-.190^{* *}$ \\
\hline Manual skilled & $.194^{* *}$ & $.250^{* *}$ & -.034 \\
\hline Semi skilled & $-.307^{* *}$ & .050 & $-.133^{* *}$ \\
\hline Unskilled & $-.314^{* *}$ & $-.155^{\circ}$ & $-203^{* *}$ \\
\hline Self employed & -.010 & -.115 & $-.389^{* *}$ \\
\hline Farmers & $-.950^{* *}$ & $-766^{* *}$ & $-.468^{* *}$ \\
\hline Agricultural workers & $-.668^{* *}$ & $-.550^{* *}$ & $-.258^{* *}$ \\
\hline Other & Ref & Ref & Ref \\
\hline \multicolumn{4}{|l|}{ Household Composition } \\
\hline Single & $.610^{* *}$ & $.569^{* *}$ & $199^{* *}$ \\
\hline Lone Parent with Children & $.485^{* *}$ & $.422^{* *}$ & $.330^{* *}$ \\
\hline Lone Parent no Children under 19 & $.677^{* *}$ & $.604^{* *}$ & $.293^{* *}$ \\
\hline Couple with Children & $.758^{* *}$ & $660^{* *}$ & $.406^{* *}$ \\
\hline Couple no Children under 19 & $.792^{* *}$ & $608^{* *}$ & $360^{* *}$ \\
\hline Couple no Children & $.941^{* *}$ & $.776^{* *}$ & $.303^{* *}$ \\
\hline Other Households & Ref & Ref & Ref \\
\hline \multicolumn{4}{|l|}{ Density per $\mathrm{km}^{2}$} \\
\hline $0-50$ persons & $1.139^{* *}$ & $1.382^{* *}$ & $.058^{*}$ \\
\hline $50-250$ persons & $.603^{* *}$ & $.864^{* *}$ & .016 \\
\hline $250-1,000$ persons & $609^{* *}$ & $.750^{* *}$ & $.148^{* *}$ \\
\hline $1,000-5,000$ persons & Ref & Ref & Ref \\
\hline Number of Cases & \multicolumn{3}{|c|}{178,448} \\
\hline Nagelkerke R-squared & \multicolumn{3}{|c|}{.086} \\
\hline Log Likelihood & \multicolumn{3}{|c|}{66670.007} \\
\hline
\end{tabular}

** Significant at $1 \%, *$ Significant at $5 \%$ 
Table 11

Click here to download high resolution image

Table 11: MNL model results (National Dataset: Medium $\mathrm{CO}_{2}$ price - $€ 16.70$ )

\begin{tabular}{|c|c|c|c|}
\hline Variable & $\begin{array}{c}\text { Large } \\
\text { negative change }\end{array}$ & $\begin{array}{c}\text { Marginal } \\
\text { negative change }\end{array}$ & $\begin{array}{c}\text { Marginal } \\
\text { positive change }\end{array}$ \\
\hline Intercept & $-6.585^{* *}$ & $-3.633^{* *}$ & $1.009^{* *}$ \\
\hline \multicolumn{4}{|l|}{ Age } \\
\hline $15-24$ & $.813^{* *}$ & $.662^{* *}$ & $.158^{* *}$ \\
\hline $25-34$ & $1.350^{* *}$ & $.975^{* *}$ & $.086^{* *}$ \\
\hline $35-44$ & $1.121^{* *}$ & $.844^{* *}$ & $.053^{*}$ \\
\hline $45-54$ & $.671^{* *}$ & $.610^{* *}$ & $.055^{*}$ \\
\hline $55-64$ & $.317^{* *}$ & $.354^{* *}$ & .041 \\
\hline $65+$ & Ref & Ref & Ref \\
\hline \multicolumn{4}{|l|}{ Gender } \\
\hline Male & $837^{* *}$ & $.267^{* *}$ & $-.082^{*}$ \\
\hline Female & Ref & Ref & Ref \\
\hline \multicolumn{4}{|l|}{ Socio-economic group } \\
\hline Employers and managers & $.446^{* *}$ & $.344^{* *}$ & $-.062^{* * *}$ \\
\hline Higher professional & $.674^{* *}$ & $.470^{* *}$ & $-.034^{*}$ \\
\hline Lower professional & $.562^{* *}$ & $.528^{* *}$ & $-.031^{*}$ \\
\hline Non-manual & $-178 * *$ & -.005 & $-.081^{*}$ \\
\hline Manual skilled & $.132 *$ & $.286^{*}$ & -.016 \\
\hline Semi skilled & $-.465^{* *}$ & $-.067^{* *}$ & $-.032^{*}$ \\
\hline Unskilled & $-.362^{* *}$ & $-.155^{* *}$ & $-.062^{* *}$ \\
\hline Self employed & $303^{* *}$ & $185^{\circ *}$ & $-.175^{* *}$ \\
\hline Farmers & $-1.801^{* *}$ & $-1.201^{* *}$ & $-.548^{* *}$ \\
\hline Agricultural workers & $-1.293^{* *}$ & $-.732^{* *}$ & $-.193^{* *}$ \\
\hline Other & Ref & Ref & Ref \\
\hline \multicolumn{4}{|l|}{ Household Composition } \\
\hline Single & $.705^{* *}$ & $.493^{* *}$ & $.024^{*}$ \\
\hline Lone Parent with Children & $.390^{* *}$ & $.309^{* *}$ & $.098^{* *}$ \\
\hline Lone Parent no Children under 19 & $.515^{* *}$ & $.485^{* *}$ & $.144^{* *}$ \\
\hline Couple with Children & $.679 * *$ & $.571^{* *}$ & $.115^{* *}$ \\
\hline Couple no Children under 19 & $.629 * *$ & $.520^{* *}$ & $.140^{* *}$ \\
\hline Couple no Children & $.956^{* *}$ & $.728^{* *}$ & $.096^{* *}$ \\
\hline Other Households & Ref & Ref & Ref \\
\hline \multicolumn{4}{|l|}{ Density per $\mathrm{km}^{2}$} \\
\hline $0-50$ persons & $2.205^{* *}$ & $1.851^{* *}$ & $-.201^{* *}$ \\
\hline $50-250$ persons & $1.890^{* *}$ & $1.625^{* *}$ & $-.119^{* *}$ \\
\hline $250-1,000$ persons & $1.875^{\circ}$ & $1.398^{* *}$ & $.039^{* *}$ \\
\hline $1,000-5,000$ persons & $.971^{* *}$ & $.799^{\circ *}$ & $.035^{* *}$ \\
\hline $5,000+$ persons & Ref & Ref & Ref \\
\hline Number of Cases & \multicolumn{3}{|c|}{$1,212,306$} \\
\hline Nacelkerke R-squared & \multicolumn{3}{|c|}{$\frac{1,212,000}{.131}$} \\
\hline Log Likelihood & & 192232.780 & \\
\hline
\end{tabular}

** Significant at $1 \%, *$ Significant at $5 \%$ 
Table 12

Click here to download high resolution image

Table 12: MNL model results (Dublin Dataset: Medium $\mathrm{CO}_{2}$ price - $€ 16.70$ )

\begin{tabular}{|c|c|c|c|}
\hline Variable & $\begin{array}{c}\text { Large } \\
\text { negative change }\end{array}$ & $\begin{array}{c}\text { Marginal } \\
\text { negative change }\end{array}$ & $\begin{array}{c}\text { Marginal } \\
\text { positive change }\end{array}$ \\
\hline Intercept & $-5.509^{* *}$ & $-3.308^{*}$ & $.807^{* *}$ \\
\hline \multicolumn{4}{|l|}{ Age } \\
\hline $15-24$ & -.273 & .125 & $.348^{* *}$ \\
\hline $25-34$ & .066 & $408^{* *}$ & $209^{* *}$ \\
\hline $35-44$ & -.005 & $.405^{* *}$ & $.151^{* *}$ \\
\hline $45-54$ & -.148 & $.262^{* *}$ & $.094^{*}$ \\
\hline $55-64$ & $-.467^{\circ}$ & .132 & .042 \\
\hline $65+$ & Ref & Ref & Ref \\
\hline \multicolumn{4}{|l|}{ Gender } \\
\hline Male & $.806^{* *}$ & $.391^{* *}$ & $-.097^{* *}$ \\
\hline Female & Ref & Ref & Ref \\
\hline \multirow{2}{*}{\multicolumn{4}{|c|}{ Socio-economic group }} \\
\hline & & & \\
\hline Employers and managers & .060 & $.413^{* *}$ & -.017 \\
\hline Higher professional & .210 & $256^{* *}$ & -.008 \\
\hline Lower professional & $-.592^{* *}$ & $.251^{* *}$ & -.029 \\
\hline Non-manual & $-.882^{* *}$ & -.052 & $.076^{* *}$ \\
\hline Manual skilled & -.045 & $.571^{* *}$ & .014 \\
\hline Semi skilled & $-.915^{* *}$ & .045 & $.092^{* *}$ \\
\hline Unskilled & -.243 & -.014 & $.152^{* *}$ \\
\hline Self employed & $.501^{*}$ & $648^{* *}$ & -.069 \\
\hline Farmers & $926^{\circ}$ & .145 & $-.715^{* *}$ \\
\hline Agricultural workers & .058 & -.362 & $-.463^{* *}$ \\
\hline Other & Ref & Ref & Ref \\
\hline \multicolumn{4}{|l|}{ Household Comnosition } \\
\hline Single & .125 & $234^{* *}$ & $-.063^{* *}$ \\
\hline Lone Parent with Children & .162 & $206^{* *}$ & $-.096^{* *}$ \\
\hline Lone Parent no Children under 19 & .072 & $.350^{* *}$ & $.102^{* *}$ \\
\hline Couple with Children & -.007 & $.394^{* *}$ & $-.087^{* *}$ \\
\hline Couple no Children under 19 & .147 & $.360^{* *}$ & .020 \\
\hline Couple no Children & .176 & $413^{* *}$ & -.025 \\
\hline Other Households & Ref & Ref & Ref \\
\hline \multicolumn{4}{|l|}{ Density per $\mathrm{km}^{2}$} \\
\hline $0-50$ persons & .774 & $2.367^{* *}$ & -.194 \\
\hline $50-250$ persons & .316 & $1.262^{* *}$ & -.019 \\
\hline $250-1,000$ persons & $.449^{* *}$ & $1.335^{* *}$ & $-.073^{* *}$ \\
\hline $1,000-5,000$ persons & $398^{* *}$ & $657^{* *}$ & $.060^{* *}$ \\
\hline $5,000+$ persons & Ref & Ref & Ref \\
\hline & \multirow{2}{*}{\multicolumn{3}{|c|}{350.437}} \\
\hline Number of Cases & & & \\
\hline Nagelkerke R-squared & \multicolumn{3}{|c|}{.043} \\
\hline Log Likelihood & \multicolumn{3}{|c|}{75526.744} \\
\hline
\end{tabular}

** Significant at $1 \%$, $*$ Significant at $5 \%$ 
Table 13

Click here to download high resolution image

Table 13: MNL model results (WBR Dataset: Medium $\mathrm{CO}_{2}$ price $-€ 16.70$ )

\begin{tabular}{|c|c|c|c|}
\hline Variable & $\begin{array}{c}\text { Large } \\
\text { negative change }\end{array}$ & $\begin{array}{c}\text { Marginal } \\
\text { negative change }\end{array}$ & $\begin{array}{c}\text { Marginal } \\
\text { positive change }\end{array}$ \\
\hline Intercept & $-4.083^{* *}$ & $-2.335^{* *}$ & $1.208^{*}$ \\
\hline \multicolumn{4}{|l|}{ Age } \\
\hline $15-24$ & $.903^{* *}$ & $.882^{* *}$ & .092 \\
\hline $25-34$ & $1,417^{*}$ & $1.145^{* *}$ & .037 \\
\hline 35.44 & $1.176^{* *}$ & $.983^{* *}$ & .048 \\
\hline $45-54$ & $.823^{\circ}$ & $.827^{* *}$ & $.125^{\circ}$ \\
\hline $55-64$ & $.448^{*}$ & $.512^{* *}$ & .114 \\
\hline $65+$ & Ref & Ref & Ref \\
\hline \multicolumn{4}{|l|}{ Gender } \\
\hline Male & $.744^{* 0}$ & .112 & $-.071^{*}$ \\
\hline Female & Ref & Ref & Ref \\
\hline \multicolumn{4}{|l|}{ Socio-economic group } \\
\hline Employers and managers & $.449 * *$ & $.211^{* *}$ & -.126 \\
\hline Higher professional & $.912^{*}$ & $.605^{* *}$ & -.076 \\
\hline Lower professional & $.791^{\circ}$ & $.676^{* *}$ & -.096 \\
\hline Non-manual & -.150 & -.043 &. .232 \\
\hline Manual skilled & .073 & $.200^{* *}$ & -.099 \\
\hline Semi skilled & $-.573^{* *}$ & -.017 & -.170 \\
\hline Unskilled & $-.454^{* *}$ & $-164^{* *}$ & -.205 \\
\hline Self employed & .148 & -.108 & -.401 \\
\hline Farmers & $-1.091^{*}$ & $-.717^{* *}$ & -.413 \\
\hline Agricultural workers & $-.734^{* *}$ & $-.532^{* *}$ & $-.231^{* *}$ \\
\hline Other & Ref & Ref & Ref \\
\hline \multicolumn{4}{|l|}{ Household Composition } \\
\hline Single & $.594^{* *}$ & $.509^{* *}$ & $.121^{* *}$ \\
\hline Lone Parent with Children & $334^{* *}$ & $.344^{* *}$ & $218^{* *}$ \\
\hline Lone Parent no Children under 19 & $.598^{* *}$ & $530^{\circ *}$ & $.187^{*}$ \\
\hline Couple with Children & $.711^{\circ}$ & $.546^{* *}$ & $.260^{* *}$ \\
\hline Couple no Children under 19 & $.797^{* *}$ & $.546^{* *}$ & $.256^{* *}$ \\
\hline Couple no Children & $.983^{*-}$ & $692^{* *}$ & $.181^{* *}$ \\
\hline Other Households & Ref & Ref & Ref \\
\hline \multicolumn{4}{|l|}{ Density per $\mathrm{km}^{2}$} \\
\hline $0-50$ persons & $.789^{* *}$ & $1.098^{* *}$ & $-.255^{* *}$ \\
\hline $50-250$ persons & $.508=$ & $.637^{* *}$ & $-.187^{* *}$ \\
\hline $250-1,000$ persons & $.537^{* *}$ & $.712^{* *}$ & $.135^{* *}$ \\
\hline $1,000-5,000$ persons & Ref & Ref & Ref \\
\hline $5,000+$ persons & $\mathrm{N} / \mathrm{a}$ & $\mathrm{N} / \mathrm{a}$ & $\mathrm{N} / \mathrm{a}$ \\
\hline & \multirow{2}{*}{\multicolumn{3}{|c|}{178,448}} \\
\hline $\begin{array}{l}\text { Number of Cases } \\
\text { Nagelkerke R-squared }\end{array}$ & \multicolumn{2}{|r|}{.086} & \\
\hline $\begin{array}{l}\text { Nageikerke R-squared } \\
\text { Log Likelihood }\end{array}$ & \multicolumn{3}{|c|}{63881.912} \\
\hline
\end{tabular}

** Significant at $1 \%,{ }^{*}$ Significant at $5 \%$ 
Table 14

Click here to download high resolution image

Table 14: MNL model results (National Dataset: $\mathrm{High} \mathrm{CO}_{2}$ price - $€ 28.73$ )

\begin{tabular}{|c|c|c|c|}
\hline Variable & $\begin{array}{c}\text { Large } \\
\text { negative change }\end{array}$ & $\begin{array}{c}\text { Marginal } \\
\text { negative change }\end{array}$ & $\begin{array}{c}\text { Marginal } \\
\text { positive change }\end{array}$ \\
\hline Intercept & $-6.146^{* *}$ & $-3.981^{* *}$ & $.721^{* *}$ \\
\hline \multicolumn{4}{|l|}{ Age } \\
\hline $15-24$ & $.856^{* *}$ & $.706^{* *}$ & $.387^{* *}$ \\
\hline $25-34$ & $1.252^{* *}$ & $.885^{* *}$ & .015 \\
\hline 35.44 & $1.021^{* 0}$ & $.751^{* *}$ & $-.084^{* *}$ \\
\hline 45.54 & $.610^{* *}$ & $.538^{* *}$ & $-.066^{* *}$ \\
\hline $55 \cdot 64$ & $.274^{* *}$ & $.310^{* *}$ & $-.045^{*}$ \\
\hline $65+$ & Ref & Ref & Ref \\
\hline \multicolumn{4}{|l|}{ Gender } \\
\hline Male & $.720^{\circ}$ & $.236^{* *}$ & $-153^{* *}$ \\
\hline Female & Ref & Ref & Ref \\
\hline \multicolumn{4}{|l|}{ Socio-economic group } \\
\hline Employers and managers & $.345^{* *}$ & $219^{* *}$ & $-387^{*}$ \\
\hline Higher professional & $.543^{* 0}$ & $.313^{* *}$ & $-.385^{* *}$ \\
\hline Lower professional & $499^{* *}$ & $.385^{* *}$ & $-.353^{* *}$ \\
\hline Non-manual & $-.117^{* *}$ & -.015 & $-165^{* *}$ \\
\hline Manual skilled & $.072^{\circ}$ & $.186^{* *}$ & $-.271^{* *}$ \\
\hline Semi skilled & $-.380^{* *}$ & $-.065^{* *}$ & $-.082^{* *}$ \\
\hline Unskilled & $-.223^{* *}$ & $-.066^{* *}$ & $.082^{* *}$ \\
\hline Self employed & $.274^{* *}$ & $.165^{* *}$ & $-.347^{* *}$ \\
\hline Farmers & $-1.322^{* *}$ & $-.862^{* *}$ & $-120^{* *}$ \\
\hline Agricultural workers & $-.987^{* 0}$ & $-.629^{* *}$ & $-.082^{* *}$ \\
\hline Other & Ref & Ref & Ref \\
\hline \multicolumn{4}{|l|}{ Household Composition } \\
\hline Single & $.543^{* *}$ & $.353^{* *}$ & $-.225^{* *}$ \\
\hline Lone Parent with Children & $.203^{* *}$ & $.140^{* *}$ & $-192^{* *}$ \\
\hline Lone Parent no Children under 19 & $.348^{* *}$ & $.286^{* *}$ & $-162^{* *}$ \\
\hline Couple with Children & $460^{* *}$ & $.351^{*}$ & $-.274^{* *}$ \\
\hline Couple no Children under 19 & $401^{*}$ & $.294^{* *}$ & $-.234^{* *}$ \\
\hline Couple no Children & $.736^{* 0}$ & $.524^{* *}$ & $-.248^{* *}$ \\
\hline Other Households & Ref & Ref & Ref \\
\hline \multicolumn{4}{|l|}{ Density per $\mathrm{km}^{2}$} \\
\hline $0-50$ persons & $1.927^{* *}$ & $1.639^{* *}$ & $-.838^{* *}$ \\
\hline $50-250$ persons & $1.708^{* *}$ & $1.513^{* *}$ & $-.421^{* *}$ \\
\hline $250-1,000$ persons & $1.666^{* *}$ & $1.252^{* *}$ & $-.173^{* *}$ \\
\hline $1,000-5,000$ persons & $.839 * *$ & $.700^{* *}$ & $-.125^{* *}$ \\
\hline $5,000+$ persons & Ref & Ref & Ref \\
\hline Number of Cases & \multicolumn{3}{|c|}{$1,212,306$} \\
\hline Nagelkerke R-squared & \multicolumn{3}{|c|}{155} \\
\hline Log Likelihood & & 208630.400 & \\
\hline
\end{tabular}

** Significant at $1 \%,{ }^{*}$ Significant at $5 \%$ 
Table 15

Click here to download high resolution image

Table 15: MNL model results (Dublin Dataset: $\mathrm{High} \mathrm{CO}_{2}$ price - €28.73)

\begin{tabular}{|c|c|c|c|}
\hline Variable & $\begin{array}{c}\text { Large } \\
\text { negative change }\end{array}$ & $\begin{array}{c}\text { Marginal } \\
\text { negative change }\end{array}$ & $\begin{array}{c}\text { Marginal } \\
\text { positive change }\end{array}$ \\
\hline Intercept & $-5.602^{* *}$ & $-3.582^{* *}$ & $480^{* *}$ \\
\hline \multicolumn{4}{|l|}{ Age } \\
\hline $15-24$ & .001 & $.139^{*}$ & $644^{* *}$ \\
\hline $25-34$ & .096 & $.337^{* *}$ & $.250^{* *}$ \\
\hline $35-44$ & .040 & $.321^{* *}$ & $.085^{\circ}$ \\
\hline $45-54$ & -.003 & $214^{* *}$ & $.075^{\circ}$ \\
\hline $55-64$ & -.324 & 100 & -.011 \\
\hline $65+$ & Ref & Ref & Ref \\
\hline \multirow{2}{*}{\multicolumn{4}{|c|}{ Gender }} \\
\hline & & & \\
\hline Male & $.694^{* *}$ & $.375^{* *}$ & $-.210^{* *}$ \\
\hline Female & Ref & Ref & Ref \\
\hline \multicolumn{4}{|l|}{ Socio-economic group } \\
\hline Employers and managers & .157 & $.268^{* *}$ & $-.379^{* *}$ \\
\hline Higher professional & .226 & $.120^{* *}$ & $-.319^{* *}$ \\
\hline Lower professional & $-.299^{\circ}$ & $154^{\circ}$ & $-.276^{* *}$ \\
\hline Non-manual & $-.605^{* *}$ & $-.100^{\circ}$ & .017 \\
\hline Manual skilled & .214 & $.426^{* *}$ & $-.274^{* *}$ \\
\hline Semi skilled & -.238 & -.008 & $.093^{* *}$ \\
\hline Unskilled & .053 & .019 & $.321^{* *}$ \\
\hline Self employed & $.737^{* *}$ & $.530^{\circ}$ & $-.345^{* *}$ \\
\hline Farmers & $1.724^{* *}$ & .309 & $-.410^{* *}$ \\
\hline Agricultural workers & .323 & -191 & $-.315^{\circ}$ \\
\hline Other & Ref & Ref & Ref \\
\hline \multicolumn{4}{|l|}{ Household Composition } \\
\hline Single & .033 & $168^{* *}$ & $-.251^{* *}$ \\
\hline Lone Parent with Children & .013 & $.144^{* *}$ & $-.318^{* *}$ \\
\hline Lone Parent no Children under 19 & -.007 & $.205^{* *}$ & $-.142^{* *}$ \\
\hline Couple with Children & -.059 & $.295^{*}$ & $-.407^{* *}$ \\
\hline Couple no Children under 19 & .012 & $231^{*}$ & $-.259 * *$ \\
\hline Couple no Children & .082 & $.312^{* *}$ & $-.278^{* *}$ \\
\hline Other Households & Ref & Ref & Ref \\
\hline \multicolumn{4}{|l|}{ Density per $\mathrm{km}^{2}$} \\
\hline $0-50$ persons & $.953^{\circ}$ & $2.343^{* *}$ & $-.478^{* *}$ \\
\hline $50-250$ persons & .231 & $1.152^{* *}$ & $-.354^{* *}$ \\
\hline $250-1,000$ persons & $.484^{* *}$ & $1.195^{* *}$ & $-.537^{* *}$ \\
\hline $1,000-5,000$ persons & $211^{* *}$ & $.509^{* *}$ & $-.260^{* *}$ \\
\hline $5,000+$ persons & Ref & Ref & Ref \\
\hline Number of Cases & \multicolumn{3}{|c|}{350,437} \\
\hline Nagelkerke R-squared & \multicolumn{3}{|c|}{.089} \\
\hline Log Likelihood & \multicolumn{3}{|c|}{82685.532} \\
\hline
\end{tabular}

** Significant at $1 \%$, ${ }^{*}$ Significant at $5 \%$ 
Table 16

Click here to download high resolution image

Table 16: MNL model results (WBR Dataset: $\mathrm{High} \mathrm{CO}_{2}$ price - $€ 28.73$ )

\begin{tabular}{|c|c|c|c|}
\hline Variable & $\begin{array}{c}\text { Large } \\
\text { negative change }\end{array}$ & $\begin{array}{c}\text { Marginal } \\
\text { negative change }\end{array}$ & $\begin{array}{c}\text { Marginal } \\
\text { positive change }\end{array}$ \\
\hline Intercept & $-3,745^{* *}$ & $-2.728^{* *}$ & $1,169^{* *}$ \\
\hline \multicolumn{4}{|l|}{ Age } \\
\hline $15-24$ & $1.091^{*}$ & $.919^{* *}$ & $297^{* *}$ \\
\hline $25-34$ & $1.395^{* *}$ & $1.048 * *$ & -.080 \\
\hline $35-44$ & $1.149^{* *}$ & $.853^{* *}$ & $-.151^{* *}$ \\
\hline $45-54$ & $.772^{* *}$ & $.675^{* *}$ & -.100 \\
\hline $55-64$ & $.401^{* *}$ & $.410^{* *}$ & -.028 \\
\hline $65+$ & Ref & Ref & Ref \\
\hline & & & \\
\hline \multicolumn{4}{|l|}{ Gender } \\
\hline Male & $.602^{* *}$ & $.109^{* *}$ & $-.075^{N 1}$ \\
\hline Female & Ref & Ref & Ref \\
\hline \multicolumn{4}{|l|}{ Socio-economic group } \\
\hline Employers and managers & $392^{* *}$ & $.126^{* *}$ & $-.348^{* *}$ \\
\hline Higher professional & $.787^{* 0}$ & $.438^{* *}$ & $-.433^{* *}$ \\
\hline Lower professional & $.746^{* *}$ & $.496^{* *}$ & $-.496^{* *}$ \\
\hline Non-manual & -.074 & -.052 & $-.398^{\circ *}$ \\
\hline Manual skilled & .048 & $.097^{*}$ & $-.385^{* *}$ \\
\hline Semi skilled & $-.412^{* *}$ & -.018 & $-.314^{* *}$ \\
\hline Unskilled & $-.232^{* *}$ & $-.112^{*}$ & $-.198^{* *}$ \\
\hline Self employed & $.231^{* *}$ & -.034 & $-.464^{* *}$ \\
\hline Farmers & $-.772^{* *}$ & $-.577^{* *}$ & $-.355^{* *}$ \\
\hline Agricultural workers & $-.424^{* *}$ & $-.446^{* *}$ & -.107 \\
\hline Other & Ref & Ref & Ref \\
\hline \multicolumn{4}{|l|}{ Household Composition } \\
\hline Single & $.337^{* *}$ & $.345^{* *}$ & $-.180^{* *}$ \\
\hline Lone Parent with Children & $.190^{* *}$ & $.097^{*}$ & $-.140^{* *}$ \\
\hline Lone Parent no Children under 19 & $329^{* *}$ & $.318^{* *}$ & $-.162^{* *}$ \\
\hline Couple with Children & $.335^{*-}$ & $.275^{* *}$ & $-.177^{* *}$ \\
\hline Couple no Children under 19 & $.444^{* *}$ & $.267^{* *}$ & $-.166^{* *}$ \\
\hline Couple no Children & $.632^{* *}$ & $.475^{* *}$ & $-.181^{* 0}$ \\
\hline Other Households & Ref & Ref & Ref \\
\hline \multicolumn{4}{|l|}{ Density per $\mathrm{km}^{2}$} \\
\hline $0-50$ persons & $.545^{* *}$ & $.776^{* *}$ & $-1.118^{* *}$ \\
\hline $50-250$ persons & $311^{* *}$ & $.435^{* *}$ & $-.681^{*}$ \\
\hline $250-1,000$ persons & $.359^{* *}$ & $.546^{* *}$ & $-.120^{* *}$ \\
\hline $1,000-5,000$ persons & Ref & Ref & Ref \\
\hline $5,000+$ persons & $\mathrm{N} / \mathrm{a}$ & N/a & $\mathrm{N} / \mathrm{a}$ \\
\hline & \multirow{2}{*}{\multicolumn{3}{|c|}{178,448}} \\
\hline Number of Cases & & & \\
\hline Nagelkerke R-squared & \multicolumn{3}{|c|}{.115} \\
\hline Log Likelihood & \multicolumn{3}{|c|}{69545.917} \\
\hline
\end{tabular}

** Significant at $1 \%,{ }^{*}$ Significant at $5 \%$ 
Figure 1

Click here to download high resolution image

\section{Figure 1: Dublin and WBR Regions}

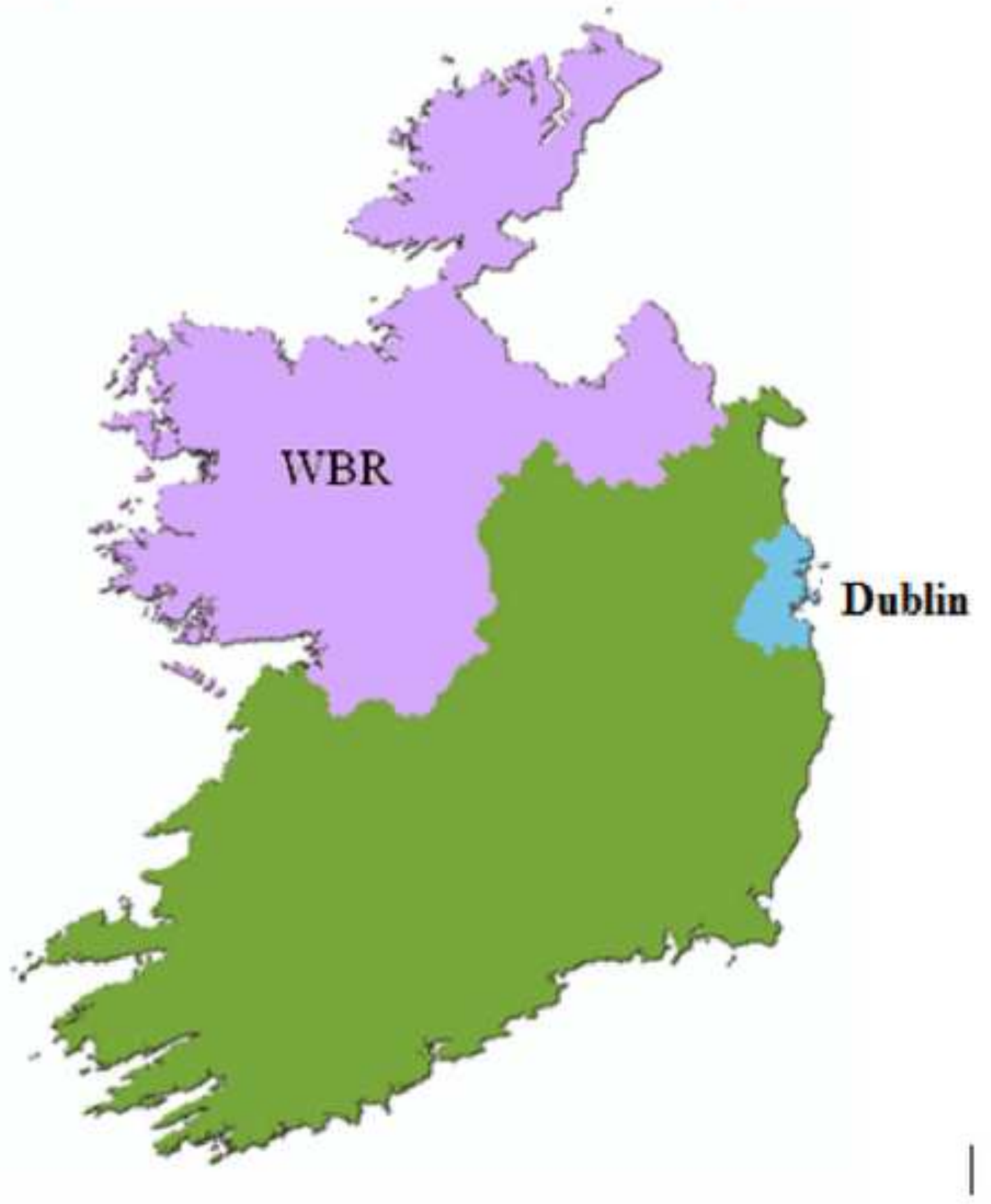




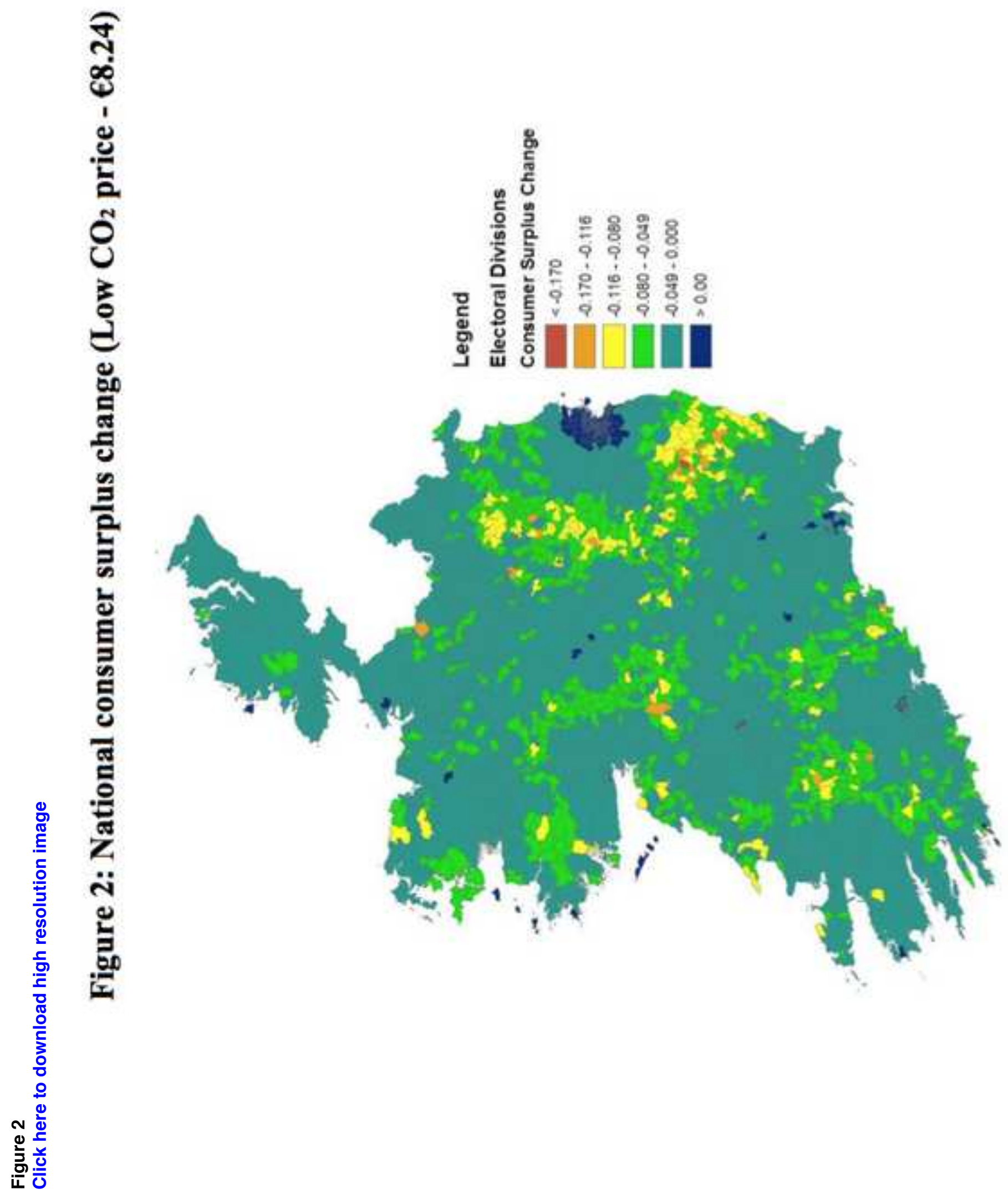




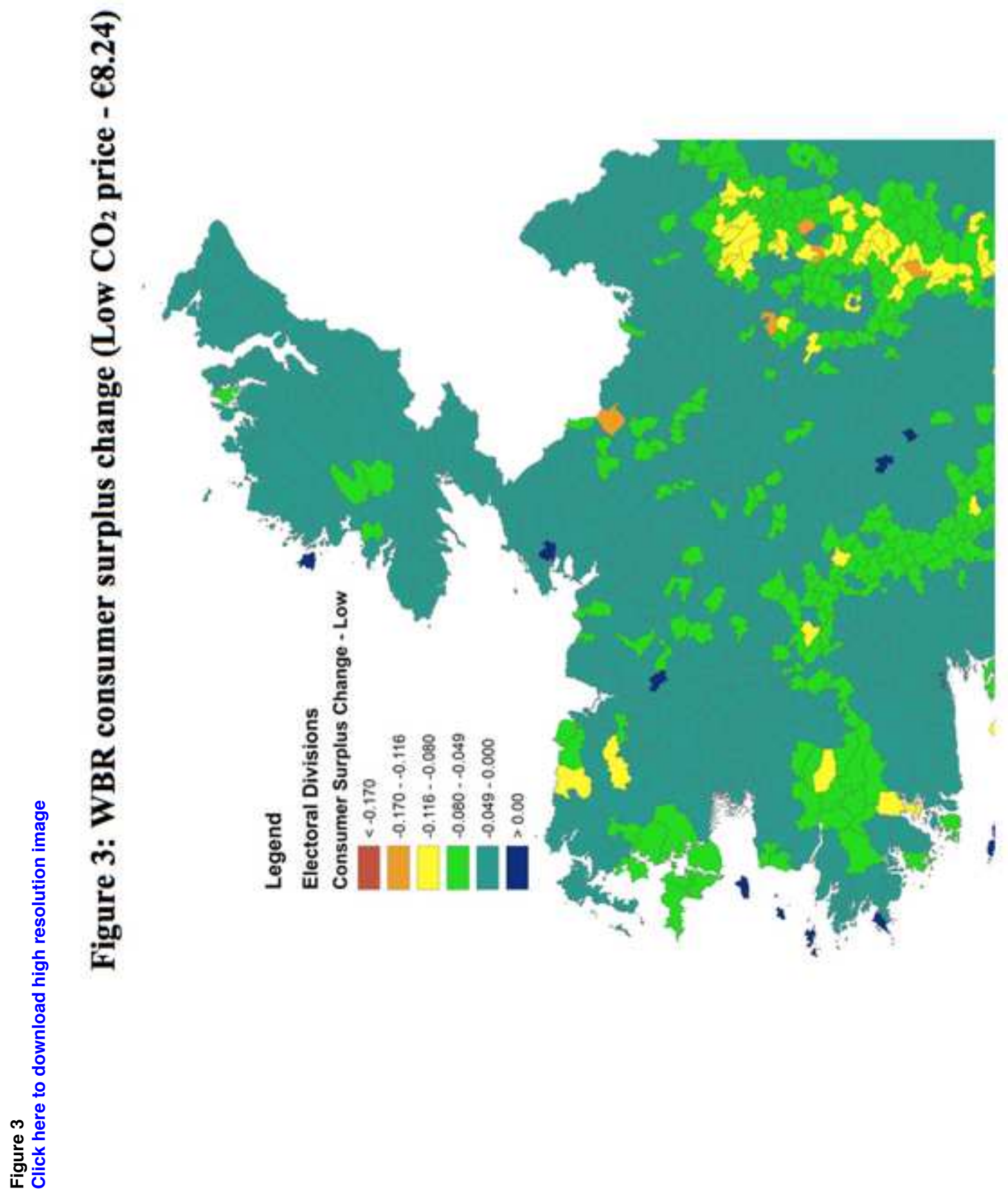




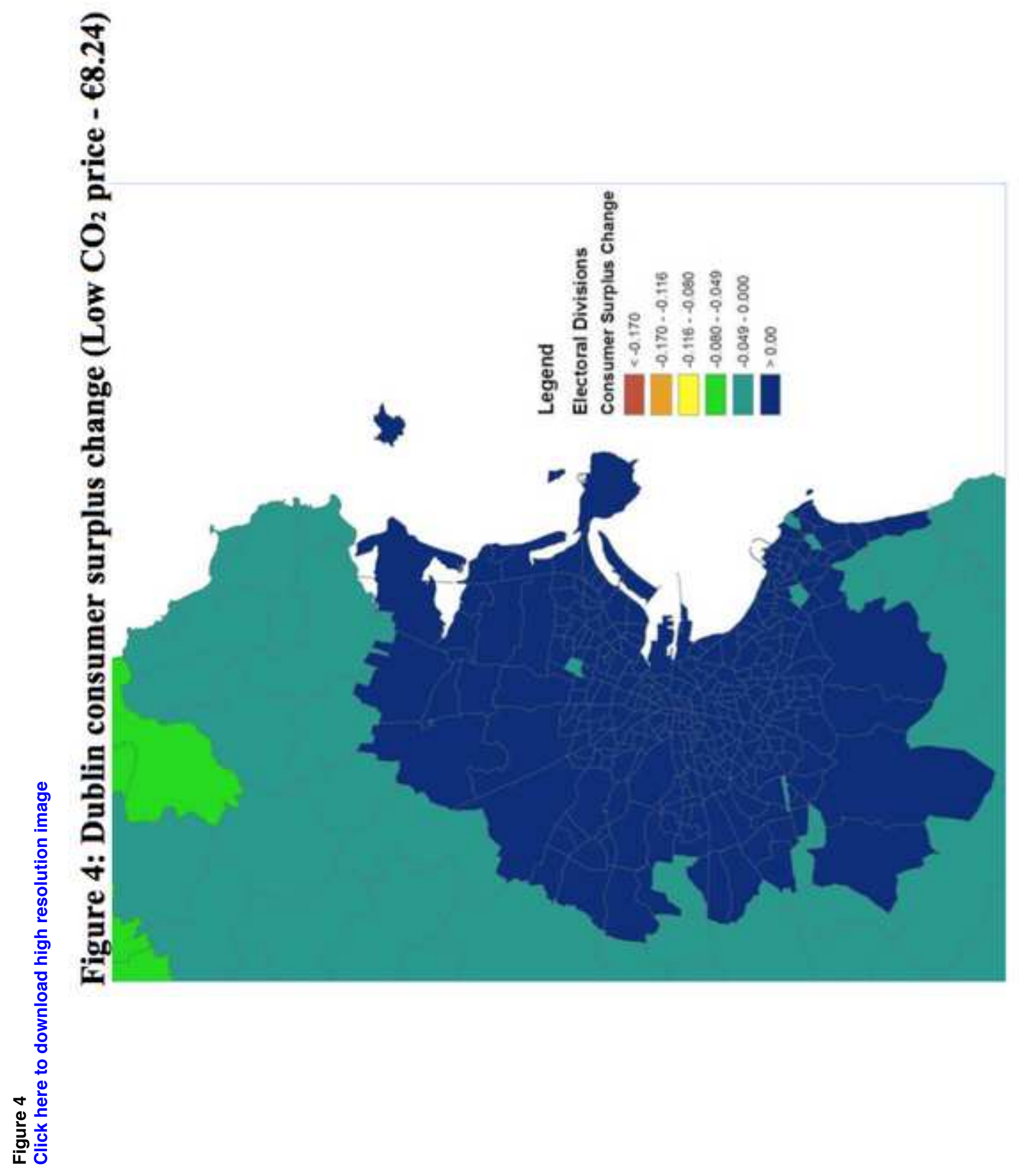




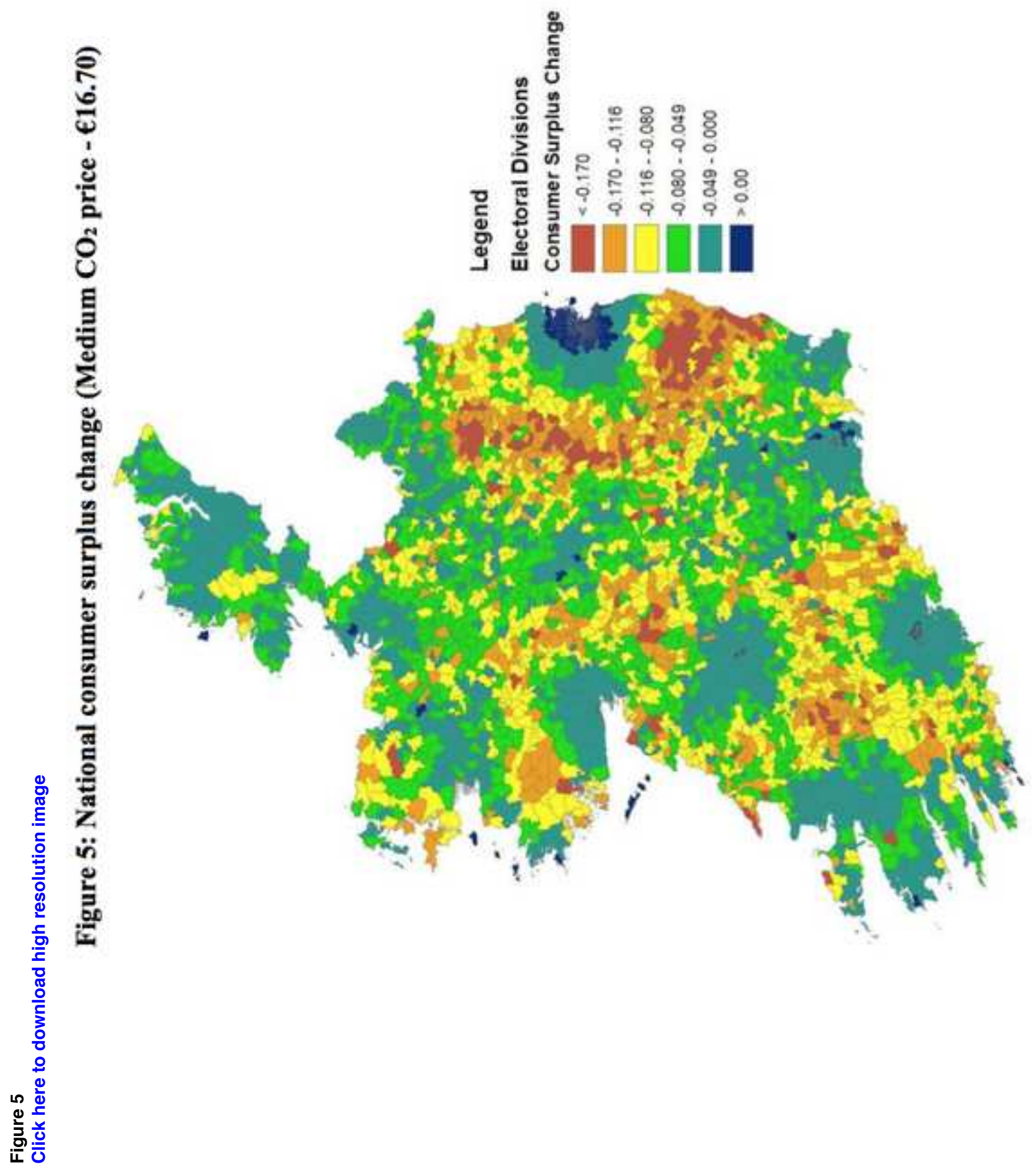




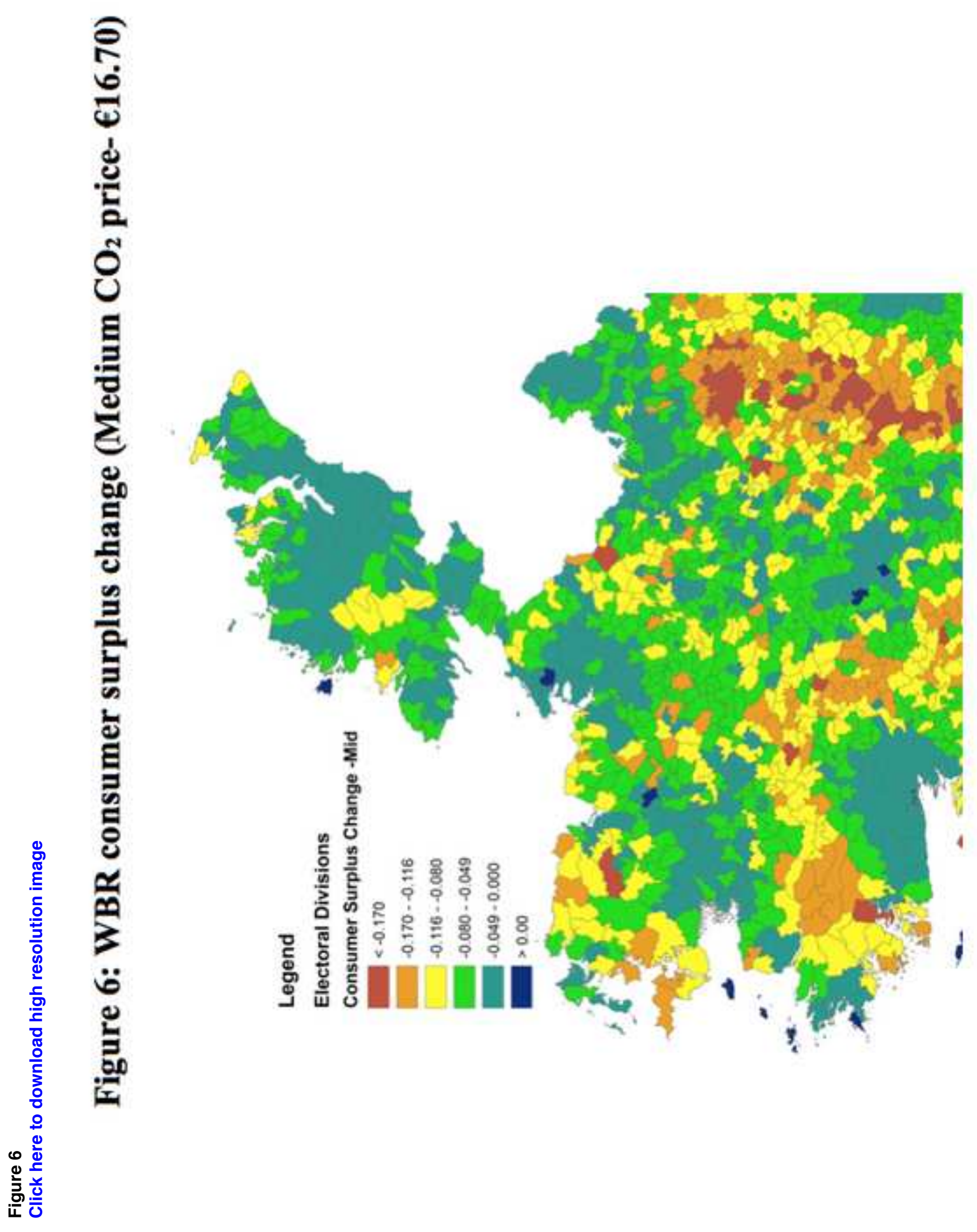




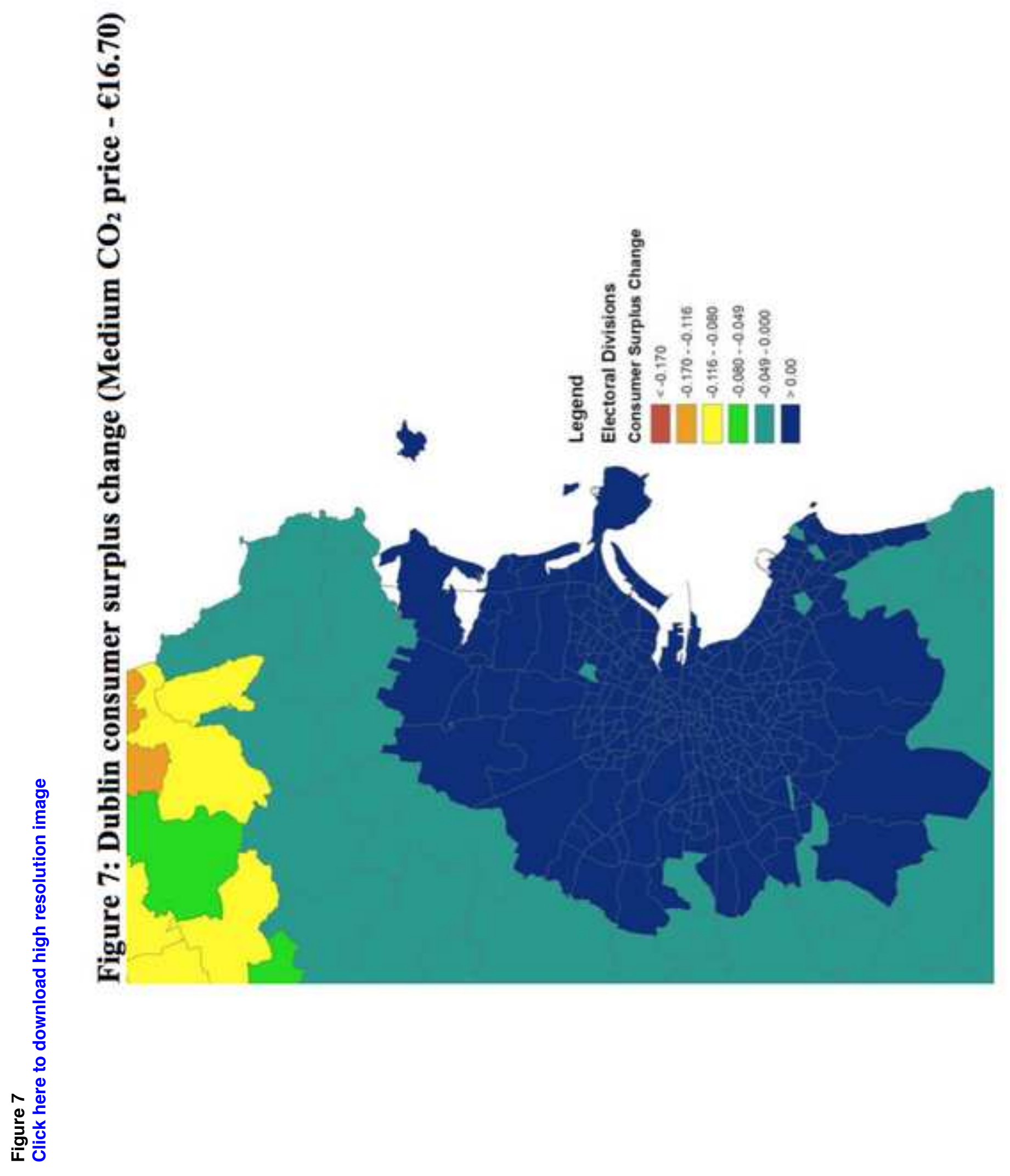




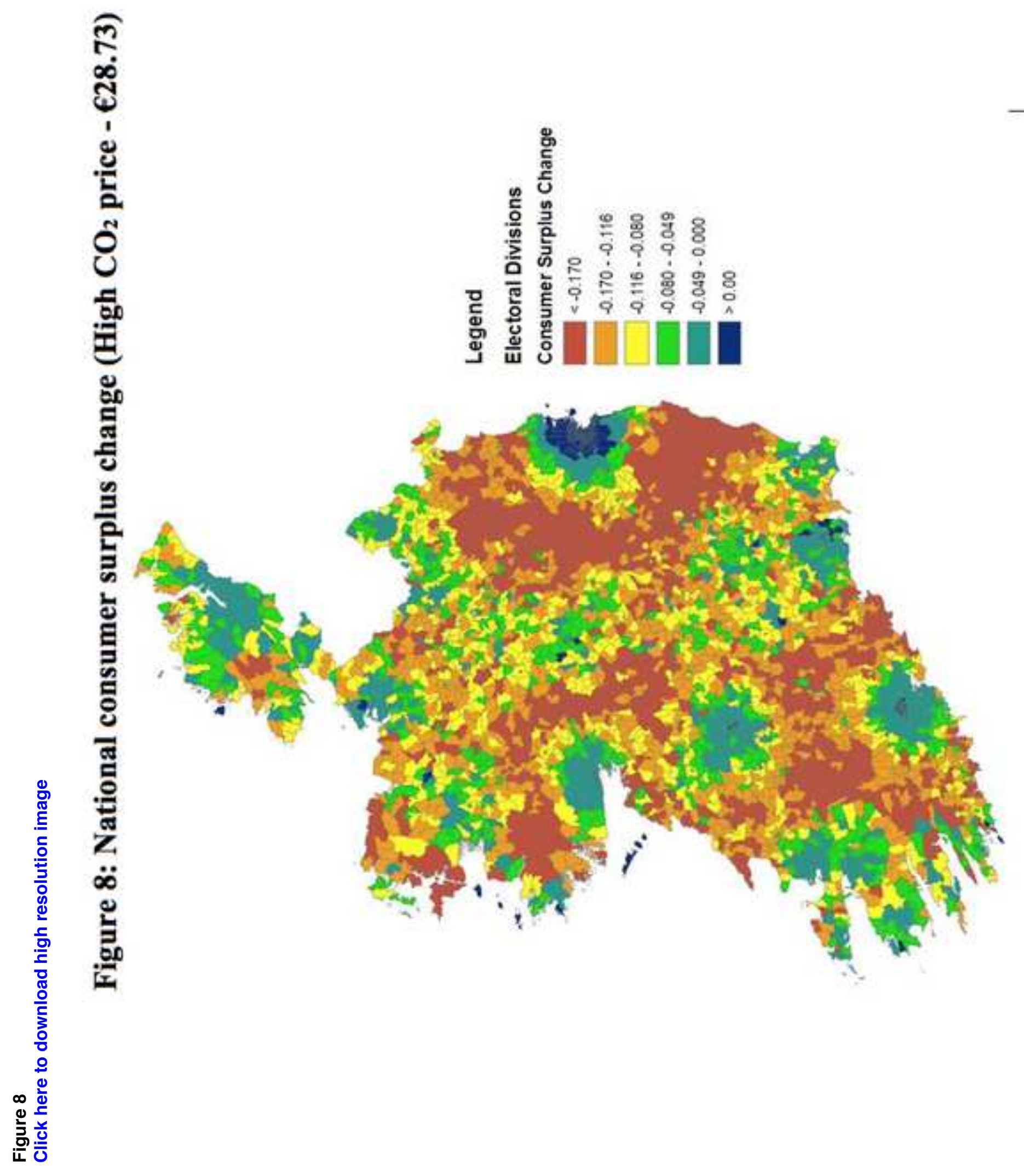




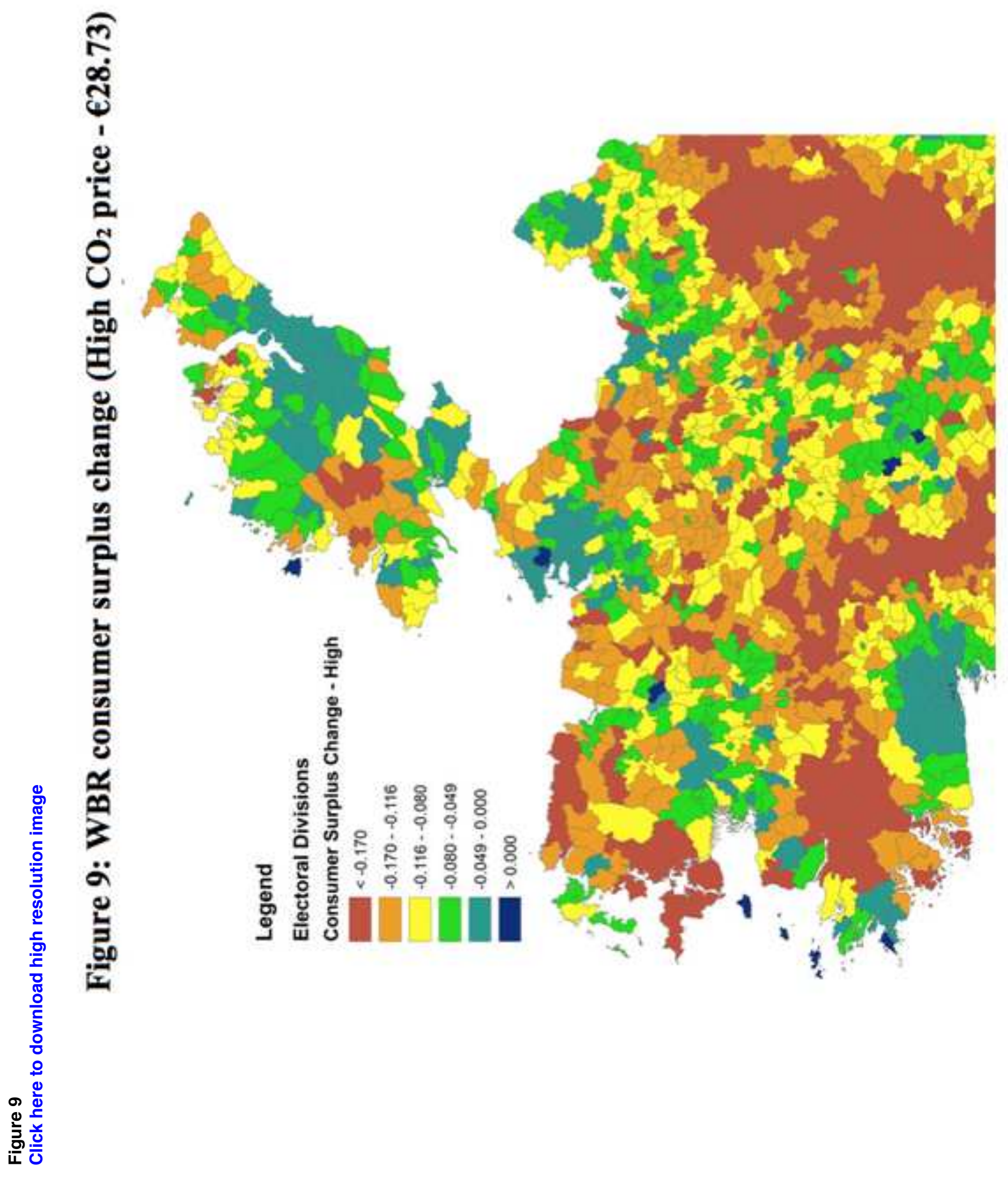




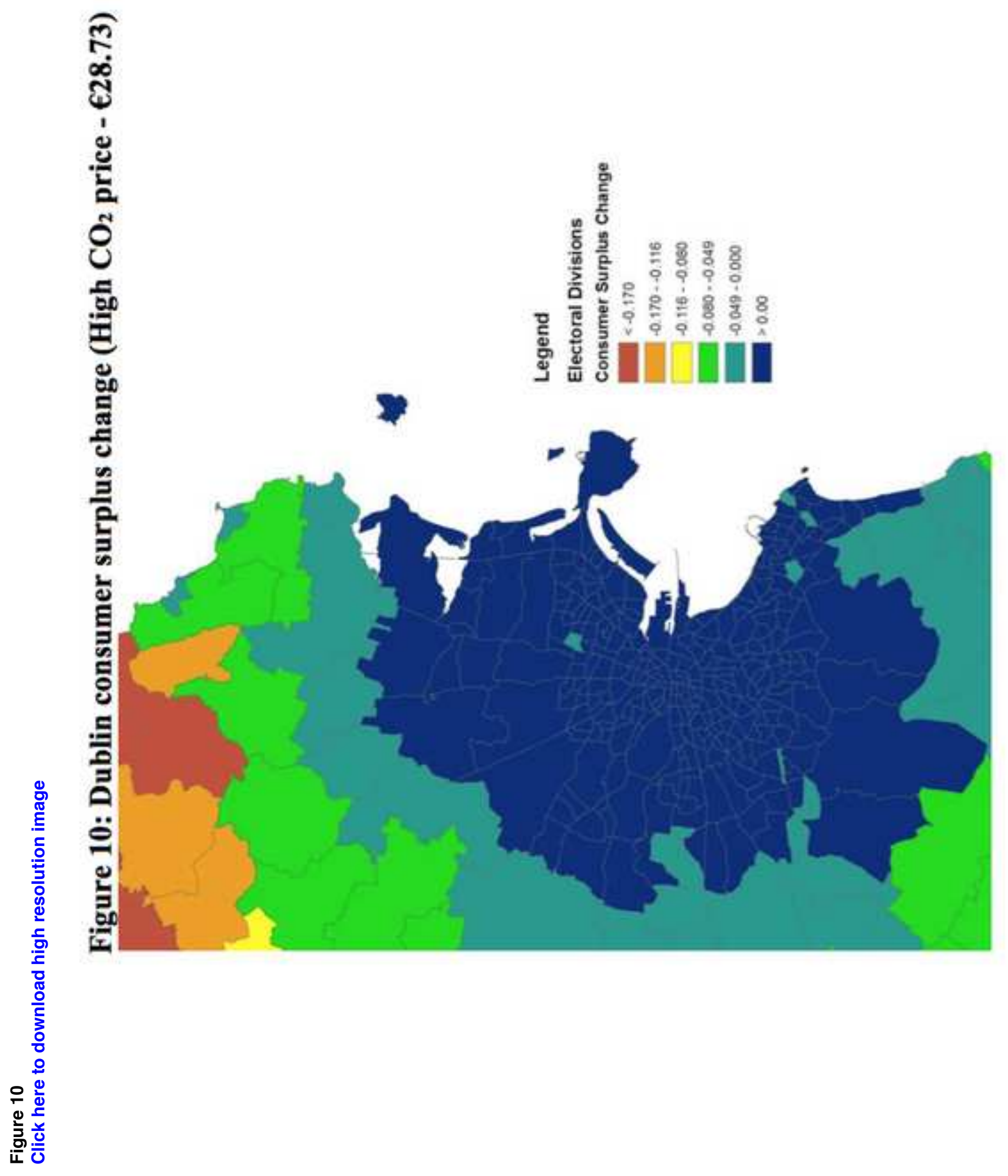

